\title{
Mineralogy and heavy metal assessment of the Pietra del Pertusillo reservoir sediments (Southern Italy)
}

\author{
Roberto Buccione $^{1}$ (1) $\cdot$ Elisabetta Fortunato ${ }^{1} \cdot$ Michele Paternoster $^{1,2} \cdot$ Giovanna Rizzo $^{1} \cdot$ Rosa Sinisi $^{1,3} \cdot$ Vito Summa $^{3}$. \\ Giovanni Mongelli ${ }^{1,3}$
}

Received: 27 April 2020 / Accepted: 13 September 2020 / Published online: 19 September 2020

(C) The Author(s) 2020

\begin{abstract}
The Pietra del Pertusillo freshwater reservoir is a major artificial lake of environmental, biological, and ecological importance located in the Basilicata region, southern Italy. The reservoir arch-gravity dam was completed in 1963 for producing hydroelectric energy and providing water for human use, and nearby there are potential sources of anthropogenic pollution such as urban and industrial activities. For the first time, the minero-chemistry of the lake and fluvio-lacustrine sediments of the reservoir have been evaluated to assess the environmental quality. Moreover, the composition of fluvial sediments derived from the peri-lacual zone of the reservoir and of local outcropping bedrock were also studied to understand the factors affecting the behavior of elements in the freshwater reservoir, with particular attention paid to heavy metals. In Italy, specific regulatory values concerning the element threshold concentration for lake and river sediments do not exist, and for this reason, soil threshold values are considered the standard for sediments of internal waters. The evaluation of the environmental quality of reservoir sediments has been performed using enrichment factors obtained with respect to the average composition of a reconstructed local upper continental crust. We suggest this method as an innovative standard in similar conditions worldwide. In the studied reservoir sediments, the trace elements that may be of some environmental concern are $\mathrm{Cr}, \mathrm{Cu}, \mathrm{Zn}, \mathrm{As}$, and $\mathrm{Pb}$ although, at this stage, the distribution of these elements appears to be mostly driven by geogenic processes. However, within the frame of the assessment and the preservation of the quality of aquatic environments, particular attention has to be paid to As (which shows median value of $10 \mathrm{ppm}$, reaching a maximum value of $26 \mathrm{ppm}$ in Quaternary sediments), constantly enriched in the lacustrine samples and especially in the fine-grained fraction (median $=8.5 \mathrm{ppm}$ ).
\end{abstract}

Keywords Heavy metals $\cdot$ Mineralogy $\cdot$ Lake sediments $\cdot$ Environmental quality $\cdot$ Risk assessment $\cdot$ Enrichment factors

\section{Introduction}

Freshwater reservoirs role great importance for investigating pollution as they are generally located close to the urban and

Responsible Editor: Philippe Garrigues

Roberto Buccione

roberto.buccione@unibas.it

1 Department of Sciences, University of Basilicata, viale dell'Ateneo Lucano 10, 8500 Potenza, Italy

2 Istituto Nazionale di Geofisica e Vulcanologia, via Ugo La Malfa, 15390156 Palermo, Italy

3 National Research Council-Institute of Methodologies for Environment Analysis, C.da S. Loja-Zona Industriale, 85050 Tito Scalo, PZ, Italy industrial sources of pollution, where contamination issues are most likely to arise (Ammar et al. 2015; Baran et al. 2016). The reservoir sediments can be sensitive indicators for monitoring contaminants in aquatic environments (Liu et al. 2018; Aung et al. 2019; Kulbat and Sokołowska 2019; Zhuang et al. 2019), acting as sinks for different pollutants. In particular, clay fraction is mainly enriched of heavy metals, especially in highly polluted sediments (Uddin 2017; Jones et al. 2019). Depending on the environmental conditions (sediment $\mathrm{pH}$, temperature, and redox status) and on the texture and composition of the sediments heavy metals may be released and back into the water column, thus impacting the overlying water quality (Mongelli et al. 2015; Ammar et al. 2015). Furthermore, the deep reservoir sediments represent the historical memory of an ecosystem, recording the past environmental changes caused by both natural and artificial events; they allow us to reconstruct the history of depositional events 
and define their possible origin (Islam et al. 2015). Due to their rapid sedimentation rates, reservoir sediments are considered being little affected by early diagenesis processes and provide preserved historical heavy metal inputs (Audry et al. 2004; Xu et al. 2017; Zhang et al. 2017).

Heavy and critical metals are among the most common environmental pollutants stressing the biotic community and are released into the environment by the weathering of rocks (e.g., Mongelli et al. 2014a) or by human activities, such as mining, industrial and domestic effluents, and combustion of fossil fuels. They may be transported by channelized flows (such as rivers and streams), or by atmospheric dust and accumulate in natural depressed areas (lakes, seas, and oceans). If it happens, metals may represent a significant part of sediment contaminants and, at some concentrations, they may become toxic to the environment (Farkas et al. 2007; Tuikka et al. 2011; Shyleshchandran et al. 2018; Christophoridis et al. 2020).

In aquatic systems, heavy metals can be dissolved into solutions as free-ions for a short time; they, in fact, commonly are suspended as colloids by adsorption onto inorganic compounds (such as iron-manganese oxides and hydroxides and clay minerals) and organic matter (the most reactive phases in aquatic environments) or precipitated with oxides and carbonates (De Vivo et al. 2004; Ammar et al. 2015). For this reason, concentration of heavy metals might serve as useful indicators for the appropriate assessment of sediment contamination.

Although the use of lacustrine sediments as environmental archives is well established, reservoir sediments have less frequently been used as temporal records and much less common studies using sediment cores from artificial river impoundments or reservoirs (Harikumar et al. 2009; Gao et al. 2018; Varol et al. 2020). Otherwise, what is known about sediment distribution in natural lakes may not apply to reservoirs because reservoirs have a component of riverine hydrodynamics that natural lakes tend to lack (Abraham et al. 1999). Abraham et al. (1999) provided useful knowledge on the processes and consequently on the factors affecting the distribution of sediments in reservoirs.

The PPR, characterized by a $95-\mathrm{m}$-height arch-gravity dam, was completed in 1963 for producing hydroelectric energy and providing water for human use to the Apulia and Basilicata regions. The reservoir has a water capacity of 155 million $\mathrm{m}^{3}$ and is characterized by strong seasonal fluctuations of the water level as high as $40 \mathrm{~m}$, mainly due to seasonal rainfall/discharge variations.

Because of its great importance from the environmental, biological, and ecological points of view, the PPR has been the subject of several studies about the quality of its waters but poor importance has been given to its fluvial and lacustrine sediments. The available studies carried out on the sediments filling the PPR are discontinuous and fragmented and, in any case, have interested only the shallow portion of lacustrine sediments thus preventing to assess the factors affecting the lake sediments composition and understand the origin of potential pollutants.

With this in mind, we present a comprehensive and detailed minero-chemical characterization of the lacustrine sediments from the PPR based on (a) the assessment of the average chemical composition of the upper continental crust close to PPR, (b) the minero-chemical composition of the detrital supply close to the entry points of the reservoir, and (c) the distribution and the concentrations of trace elements in the bulk and fine fraction $(<4 \mu)$ of deep lacustrine sediments. Moreover, the composition of fluvial sediments derived from the peri-lacual zone of the reservoir and of local outcropping bedrock (Meso-Cenozoic rocks and Quaternary fluviolacustrine deposits) were also studied. The goal of the present paper is to understand the environmental factors influencing the geochemical behavior of elements in an artificial freshwater reservoir which role a critical impact for a great number of people and environment health, with particular attention to heavy metals, providing a model useful in other similar scenarios worldwide.

\section{Material and methods}

\section{Study area and geological setting}

The Pietra del Pertusillo reservoir (hereafter PPR) is an NWSE-elongated artificial lake located in the southwestern Basilicata region (southern Italy). The reservoir is located in the High Agri Valley (hereafter HAV), which extends over a length of about $30 \mathrm{~km}$ and a maximum width of about $12 \mathrm{~km}$, with an average altitude of $600 \mathrm{~m}$ a.s.l. and a surface of about $140 \mathrm{~km}^{2}$ (Fig. 1). It is mainly sourced by the Agri River, which enters longitudinally the lake basin from the West, whereas other minor lateral tributaries on both northern and southern margins, and during the high-stand periods, are also present, with a torrential-type discharge regime.

The total volume of sediments accumulated in the reservoir in the period 1963-2007 was about 7,420,000 $\mathrm{m}^{3}$ with the greatest sedimentation in the pre-reservoir Agri channel; here, the sediment thickness reaches a maximum value of about $8.7 \mathrm{~m}$ in the deepest area of the reservoir, near its dam, where the approximate average sedimentation rate reaches the maximum value of about $19.7 \mathrm{~cm} / \mathrm{yr}$.

The High Agri Valley is a Quaternary NW-SE intermontane basin located in the axial zone of the Southern Apennines mountain belt, an east-verging fold-and-thrust belt developed as an accretionary wedge from the late Oligocene to the early Pleistocene, due to the eastward migration of the Apenninic arc (Fig. 1) (e.g., Giano 2011; Giocoli et al. 2015; Gueguen et al. 2015). The tectonic units, derived from the deformation of the Afro-Adriatic paleomargin, are represented from west 
Fig. 1 Geology of the three main paleogeographic domains of Southern Apennines (modified from Prosser et al. 1996)

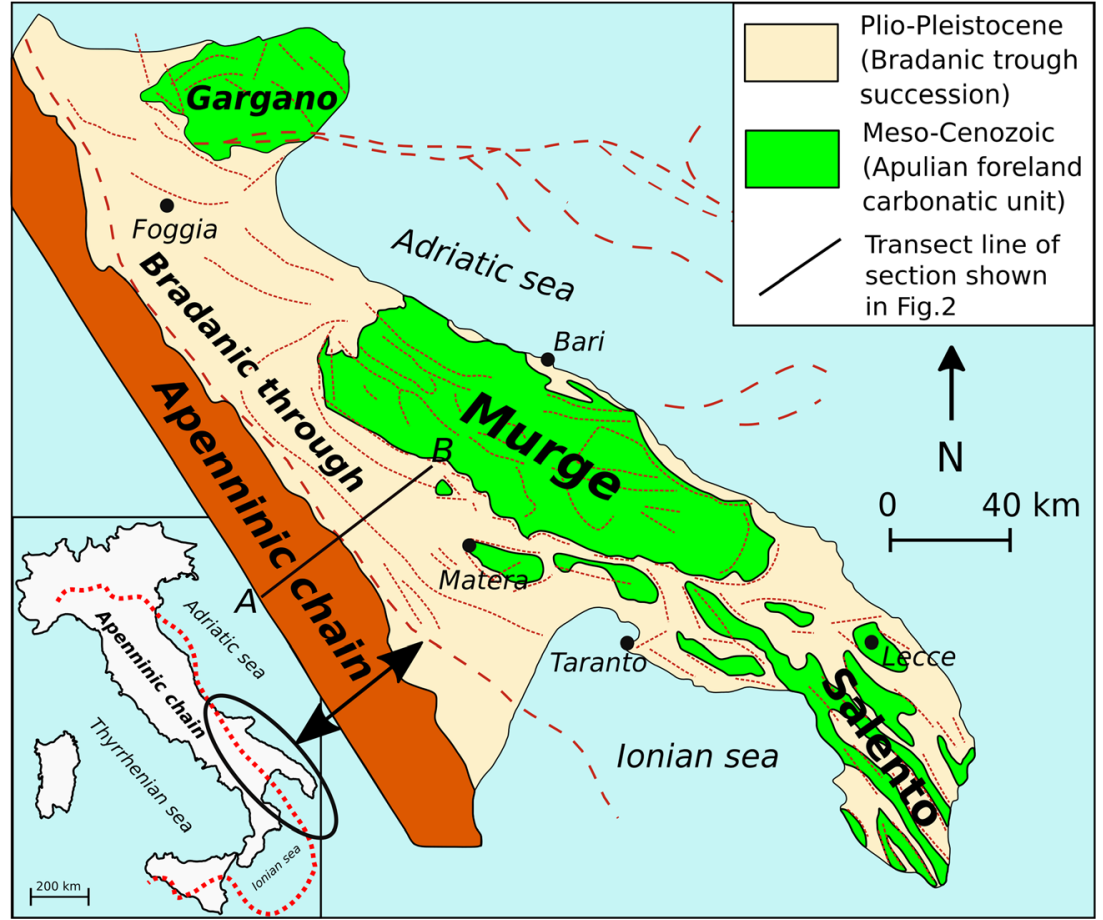

to east by the Liguride and Sicilide complexes (Cretaceous to Eocene), derived from the Liguria-Piedmont Ocean; the Apennine Platform carbonates (late Triassic to Tertiary) and the several units mainly composed of deep-sea sediments of the Lagonegro basin (late Paleozoic/Triassic to Tertiary) (Zembo 2010; Giano 2011; Gueguen et al. 2015). These units (Fig. 2), representing the substratum of the HAV, were tectonically emplaced over Plio-Pleistocene foredeep basins located on top of the Apulian Carbonate Platform.

Quaternary tectonics is still active along the axis of the chain where normal faulting displaces the Pleistocene sediments. Toward the east and southeast, the bedrock consists of Tertiary siliciclastic sediments, namely, Albidona and Gorgoglione Flysch formations. The first formation (Albidona Flysch) is composed by an alternating grayyellowish sandstone, marl, and silty clays with whitish carbonate intercalations outcropping in the eastern portion of the
HAV basin. The Gorgoglione Flysch formed in a piggyback trough during the Apenninic orogenic compressional stage. This formation is mainly composed of three terrigenous sediment sequences outcropping in the eastern portion of the HAV basin (Carbone et al. 1991; Giano 2011). Continental clastic Quaternary units also crop out on both the right and left sides of the HAV, where about $100 \mathrm{~m}$ are exposed; it is a group of clastic units of mid-upper Pleistocene age, reflecting a progradation of fan systems in a lacustrine-palustrine setting, followed by expansion of a new alluvial-fluvial system (Zembo 2010).

\section{Sampling strategy}

The sampling campaign (Figs. 3 and 4) was performed in November 2013 and May 2014 and, with this in mind, several specimens were collected (Table 1) as follows:

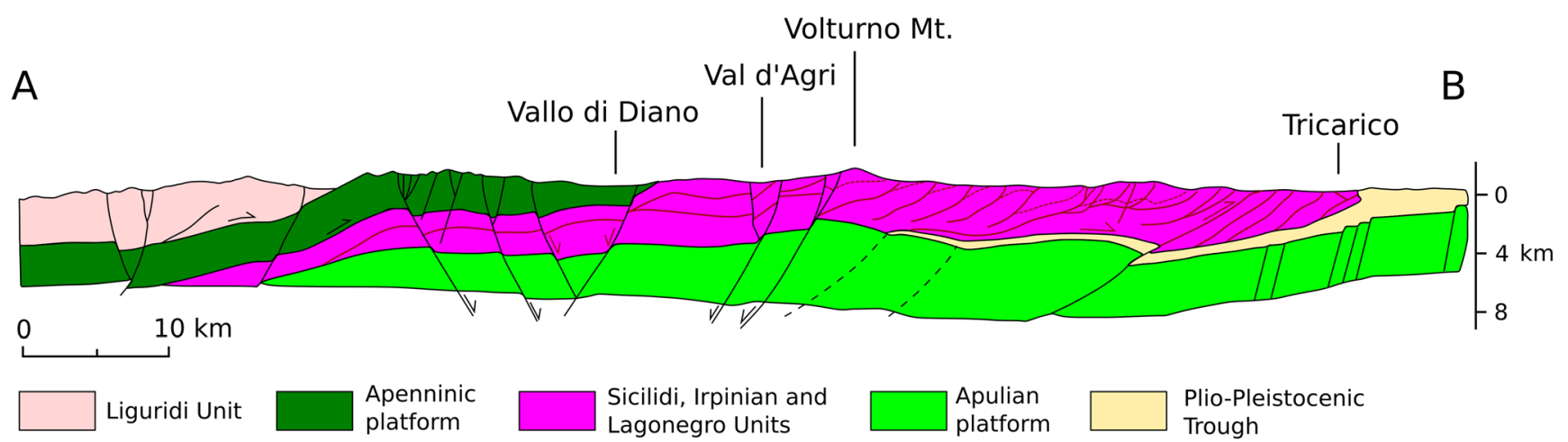

Fig. 2 Relationships between the different tectonic units in the Southern Apennines (modified from Prosser et al. 1996) 
Table 1 Collected samples. For Meso-Cenozoic lithoid samples, relative lithoid formation is reported as well

\begin{tabular}{|c|c|c|c|c|}
\hline $\begin{array}{l}\text { Lacustrine } \\
\text { sediments (bulk fr.) }\end{array}$ & $\begin{array}{l}\text { Lacustrine } \\
\text { sediments (clay fr.) }\end{array}$ & $\begin{array}{l}\text { Fluvio-lacustrine } \\
\text { sediments }\end{array}$ & $\begin{array}{l}\text { Meso-Cenozoic } \\
\text { deposits }\end{array}$ & $\begin{array}{l}\text { Quaternary } \\
\text { incoherents sediments }\end{array}$ \\
\hline F1 3 & F1 3 & EFF1 & Moliterno fm. & EF39 \\
\hline F1 6 & F1 6 & EFF2 & EF1 & EF41 \\
\hline F1 12 & F1 12 & EFF3 & EF5 & EF49 \\
\hline $\mathrm{a} / \mathrm{R}$ & $\mathrm{a} / \mathrm{R}$ & EFF4 & EF6 & EF50 \\
\hline R9 & R9 & EFF5 & EF81 & EF51 \\
\hline $\mathrm{R} 12$ & $\mathrm{R} 12$ & EFF6 & EF82 & EF52 \\
\hline R18 & $\mathrm{R} 18$ & EFF7 & Albidona fm. & EF54 \\
\hline $\mathrm{T} 1$ & $\mathrm{~T} 1$ & EFF8 & EF16 & EF60 \\
\hline $\mathrm{a} / \mathrm{T}$ & $\mathrm{a} / \mathrm{T}$ & EFF9 & EF79 & EF61 \\
\hline $\mathrm{c} / \mathrm{T}$ & $\mathrm{c} / \mathrm{T}$ & EFF10 & EF84 & EF62 \\
\hline $\mathrm{a} / \mathrm{V}$ & $\mathrm{a} / \mathrm{V}$ & EFF11 & EF57 & EF63 \\
\hline $\mathrm{b} / \mathrm{V}$ & $\mathrm{b} / \mathrm{V}$ & EFF12 & EF91 & EF65 \\
\hline $\mathrm{c} / \mathrm{V}$ & $\mathrm{c} / \mathrm{V}$ & EFF13 & $\begin{array}{l}\text { Gorgoglione } \\
\quad \mathrm{fm} \text {. }\end{array}$ & EF67 \\
\hline $\mathrm{d} / \mathrm{V}$ & $\mathrm{d} / \mathrm{V}$ & EFF14 & EF22 & EF71 \\
\hline V3 & V3 & - & EF26 & EF74 \\
\hline- & - & - & EF83 & - \\
\hline- & - & - & EF78 & - \\
\hline- & - & - & EF 59 & - \\
\hline- & - & - & Galestri fm. & - \\
\hline- & - & - & EF28 & - \\
\hline- & - & - & EF30 & - \\
\hline- & - & - & EF76 & - \\
\hline- & - & - & EF77 & - \\
\hline- & - & - & EF88 & - \\
\hline- & - & - & EF89 & - \\
\hline- & - & - & Scisti silicei fm. & - \\
\hline- & - & - & EF80 & - \\
\hline- & - & - & EF85 & - \\
\hline- & - & - & EF90 & - \\
\hline- & - & - & Liguridi & - \\
\hline- & - & - & EF86 & - \\
\hline- & - & - & EF87 & - \\
\hline- & - & - & $\begin{array}{l}\text { Monte Facito } \\
\quad \mathrm{fm} .\end{array}$ & - \\
\hline - & - & - & EF34 & - \\
\hline
\end{tabular}

- In the surrounding area of the reservoir, twenty-seven Meso-Cenozoic parent rock samples, with a predominate siliciclastic pelitic fraction

- Fifteen silty-clayey samples from the Quaternary fluviolacustrine deposits, outcropping in the drainage basin and, during the low-standing periods, along the shores of the reservoir

- Fourteen fluvio-lacustrine sediments samples. These samples were collected at the confluences of the active tributaries of the reservoir

- Fifteen samples from lake-bottom sediments, from 4 sediment cores (F, R, T, and V), lacustrine sediments were investigated, with a small platform that allowed to drill cores up to $2 \mathrm{~m}$ long from the sediment/water interface

\section{Mineralogical and chemical analyses}

The Quaternary and fluvio-lacustrine sediments were wetly sieved, using a stainless steel ASTM 2-mm mesh sieve to separate the gravel from the sand and an ASTM $63 \mu \mathrm{m}$ sieve to separate the sand from the silt-clay fraction. The sandy samples were dried at $105{ }^{\circ} \mathrm{C}$, while the silt and 
Fig. 3 Sampling points of the twenty-seven Meso-Cenozoic lithoid samples

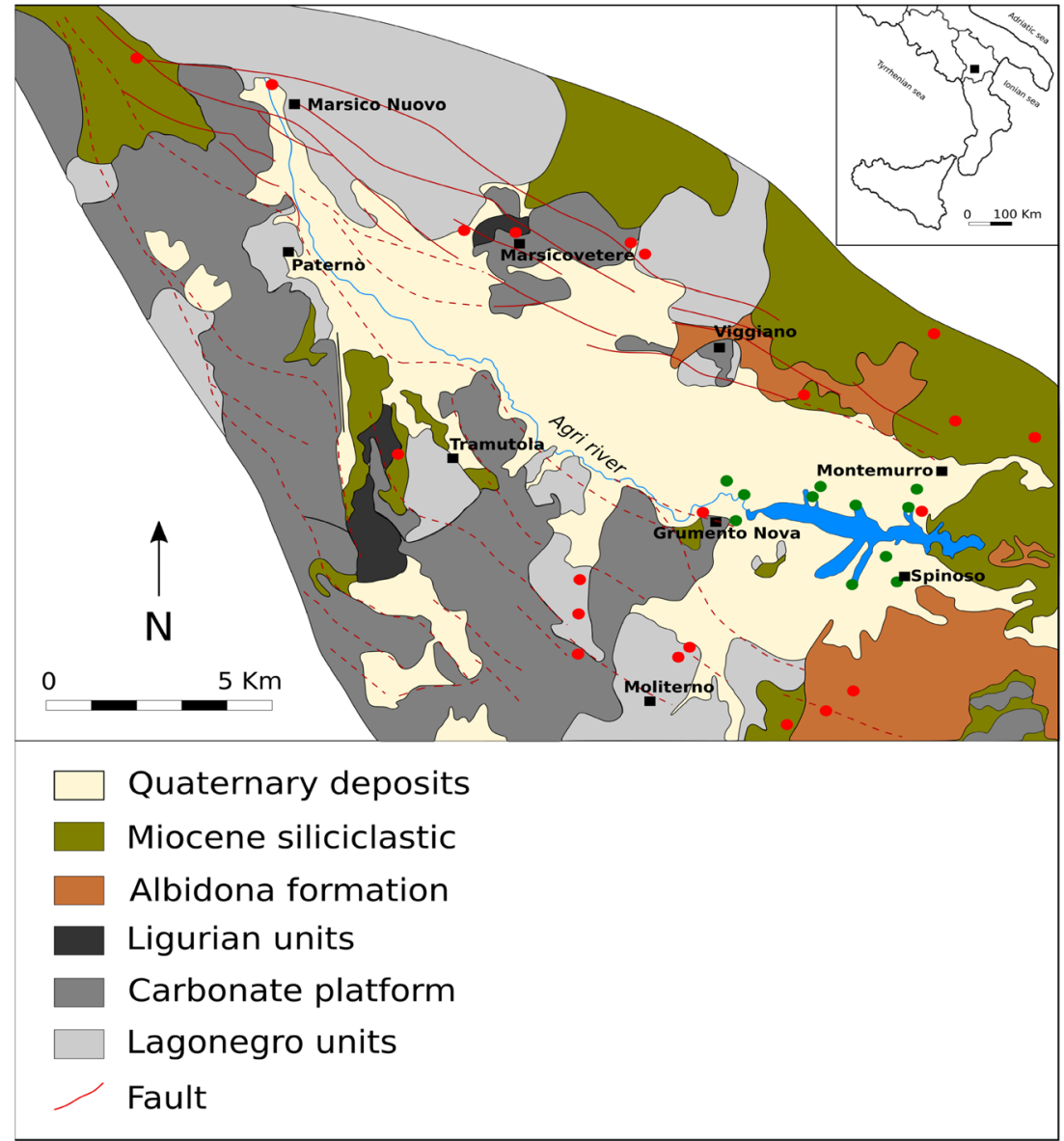

clay fractions were preserved at room temperature to avoid deconstruction of the clays. Each sample was quartered and then a proper aliquot was hand-pulverized in an agate mill jar.
The selected lacustrine samples were wet sieved with stainless steel ASTM $63 \mu \mathrm{m}$ sieve; the fraction $<4 \mu \mathrm{m}$ was obtained by fractionated sedimentation. According to Stokes' law, each sample after mechanical agitation of $8 \mathrm{~h}$, was left
Fig. 4 Samples position of quaternary bedrock deposits, fluvio-lacustrine sediments, and lake sediments cores (modified from Carbone et al. 1991)

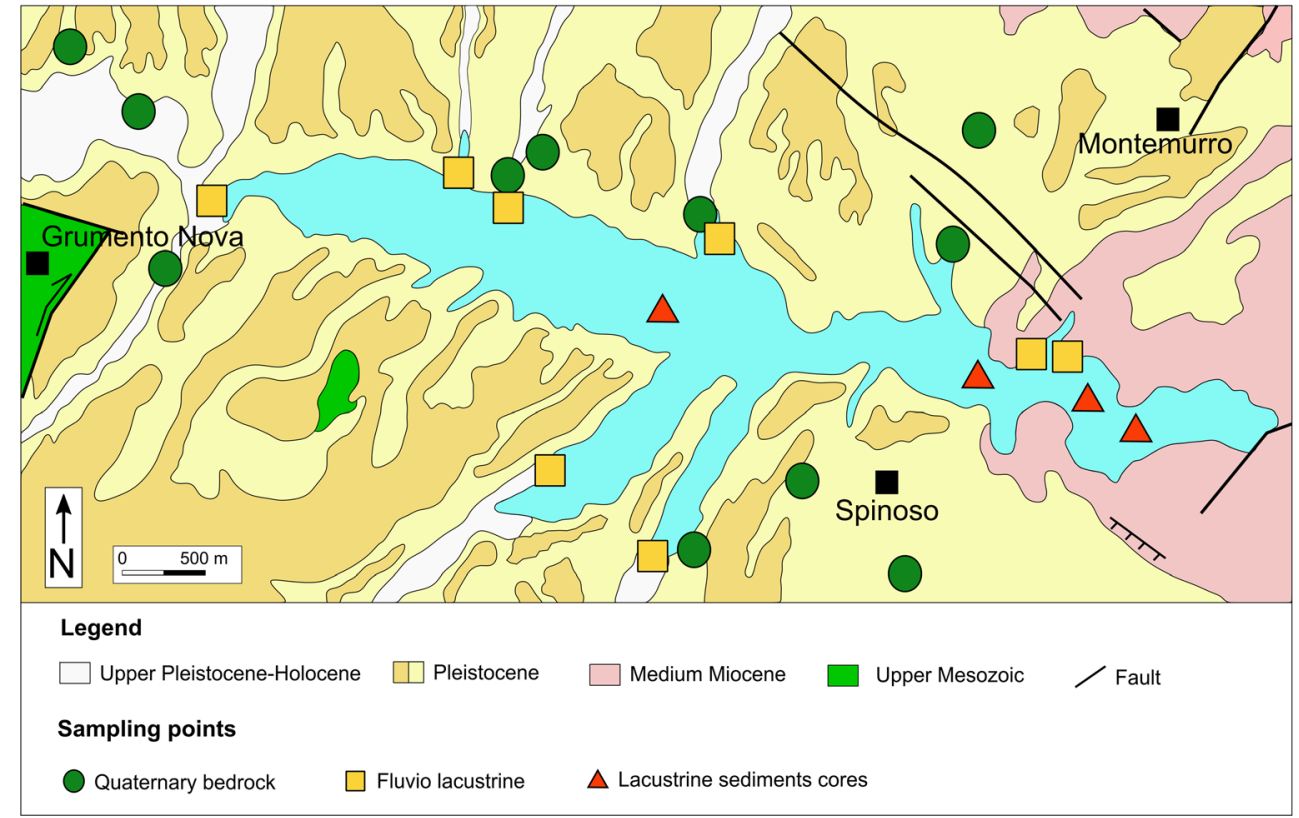


to settle for a time of $1 \mathrm{~h} 57 \mathrm{~min}$ (the time calculated for a temperature of $22{ }^{\circ} \mathrm{C}$ which is the temperature recorded in the laboratory during the extraction procedures) from a drop height of $10 \mathrm{~cm}$; once this time lapsed, the suspension was removed by siphoning. Extraction was repeated until the complete removal of the suspended solid.

Mineralogical analyses (Fig. 5) were performed on Quaternary fluvio-lacustrine samples related to the main tributaries of the reservoir and on the bottom lake lacustrine sediments.

Semiquantitative mineralogical analysis of the lacustrine and fluvio-lacustrine sediments (fraction lower than $63 \mu \mathrm{m}$ ) was determined by X-ray diffraction (X'Pert PRO Panalitycal diffractometer for powders) on non-oriented powders (random powder), obtained with the "top-loading" method of the sample holder. The X-ray diffraction analysis of the fluviolacustrine sediments (14 samples) was carried out at a scan interval of $2-70^{\circ} 2 \vartheta$, using acquisition steps of $0.02^{\circ} 2 \vartheta$; on the lacustrine sediments ( 15 samples), the scan interval was $5-$ $35^{\circ} 2 \vartheta$, using acquisition steps of $0.01^{\circ} 2 \vartheta$, time per step $=1 \mathrm{~s}$; copper radiation $\mathrm{Cu}-\mathrm{K} \alpha 1,2=1.54184$ was used.

Powdered samples were digested using a four acid attack ( $\mathrm{HF}, \mathrm{HNO}_{3}, \mathrm{HClO}_{4}$, and $\mathrm{HCl}$ ). A 0.25 -g sample is first digested using hydrofluoric acid; then, the sample is treated in a mixture of nitric and perchloric acids before being heated in several ramping and holding cycles, taking the samples to incipient dryness. Next, the samples are brought back into solution using aqua regia before being analyzed. Major and trace elements were determined by inductively coupled plasma optical mass spectrometry (ICP-MS), using a PerkinElmer Sciex ELAN 9000 at Activation Laboratories (Ancaster, Canada).

Analytical data quality was checked by using NIST694 and DNC-1(for major element), JR-1 (for As and Pb), and GXR-4 (for Cr, Ni, and V) Standard Reference Materials (SRM) and by calculating the average relative error. SRM of known elemental composition play an important role in the quality assurance (QA). For most elements, the recovery quality assurance/ quality control (QA/QC) ranges between 80 and $110 \%$. Analytical uncertainties are less than $\pm 5 \%$, except for elements at concentrations of $\leq 10 \mathrm{ppm}$ which have uncertainties of \pm 5 $10 \%$. Total loss-on-ignition (LOI) values was gravimetrically estimated after overnight heating at $950^{\circ} \mathrm{C}$. Total organic carbon (TOC) was evaluated, by loss-on-ignition, only for lacustrine sediments. Three grams of wet sediment was placed in a drying oven at $60{ }^{\circ} \mathrm{C}$ for $48 \mathrm{~h}$ then cooled in a desiccator and weighted, subsequently was placed in a muffle furnace at $500{ }^{\circ} \mathrm{C}$ for $8 \mathrm{~h}$, and finally cooled in a desiccator and weighted for the no-organic matter dried sediment $\left(\mathrm{wt}_{60^{\circ} \mathrm{C}} \mathrm{C}\right.$. After a week, the samples were re-introduced in the muffle furnace at $500{ }^{\circ} \mathrm{C}$ for $8 \mathrm{~h}$ and then reweighted $\left(\mathrm{wt}_{500^{\circ} \mathrm{C}}\right)$.
Fig. 5 (a) Mineralogy composition of lake sediments. (b) Mineralogy composition of fluvio-lacustrine samples

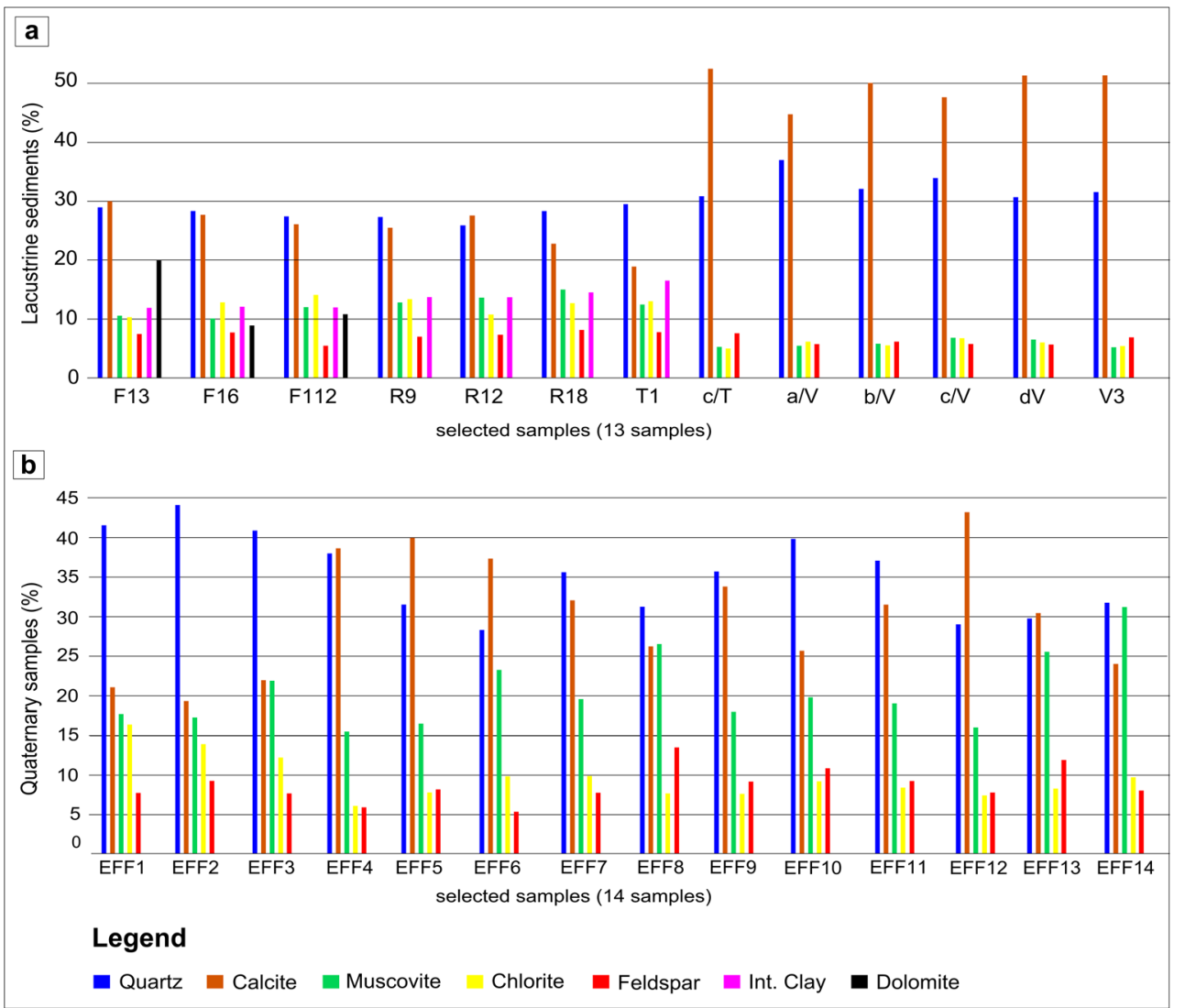


The percentage of organic matter was calculated by the following formula (Hakanson and Jansson 1983):

$\mathrm{TOC}=\left(\mathrm{wt}_{60{ }^{\circ} \mathrm{C}}-\mathrm{wt}_{500^{\circ} \mathrm{C}}\right) /\left(\mathrm{wt}_{60}{ }^{\circ} \mathrm{C}\right) \times 100$,

where $\mathrm{wt}_{60}{ }^{\circ} \mathrm{C}$ and $\mathrm{wt}_{500^{\circ} \mathrm{C}}$ are the weight of sample after heating at $60{ }^{\circ} \mathrm{C}$ for $48 \mathrm{~h}$ and at $500{ }^{\circ} \mathrm{C}$ for $8 \mathrm{~h}$, respectively.

\section{Statistical data treatment}

Used statistical data relative to the analyzed samples are reported in Fig. 6 with the box-and-whiskers plot.

In particular, among the statistical data, for each set of sample's minimum value, maximum value, and the relative range (difference between maximum and minimum values) were calculated. Then, the 25th, 50th (median), and 75th percentile of each data set have been calculated. In relation to the latter data, interquartile range (IQR) (being equal to the difference between 75 th and 25 th percentiles or between upper and
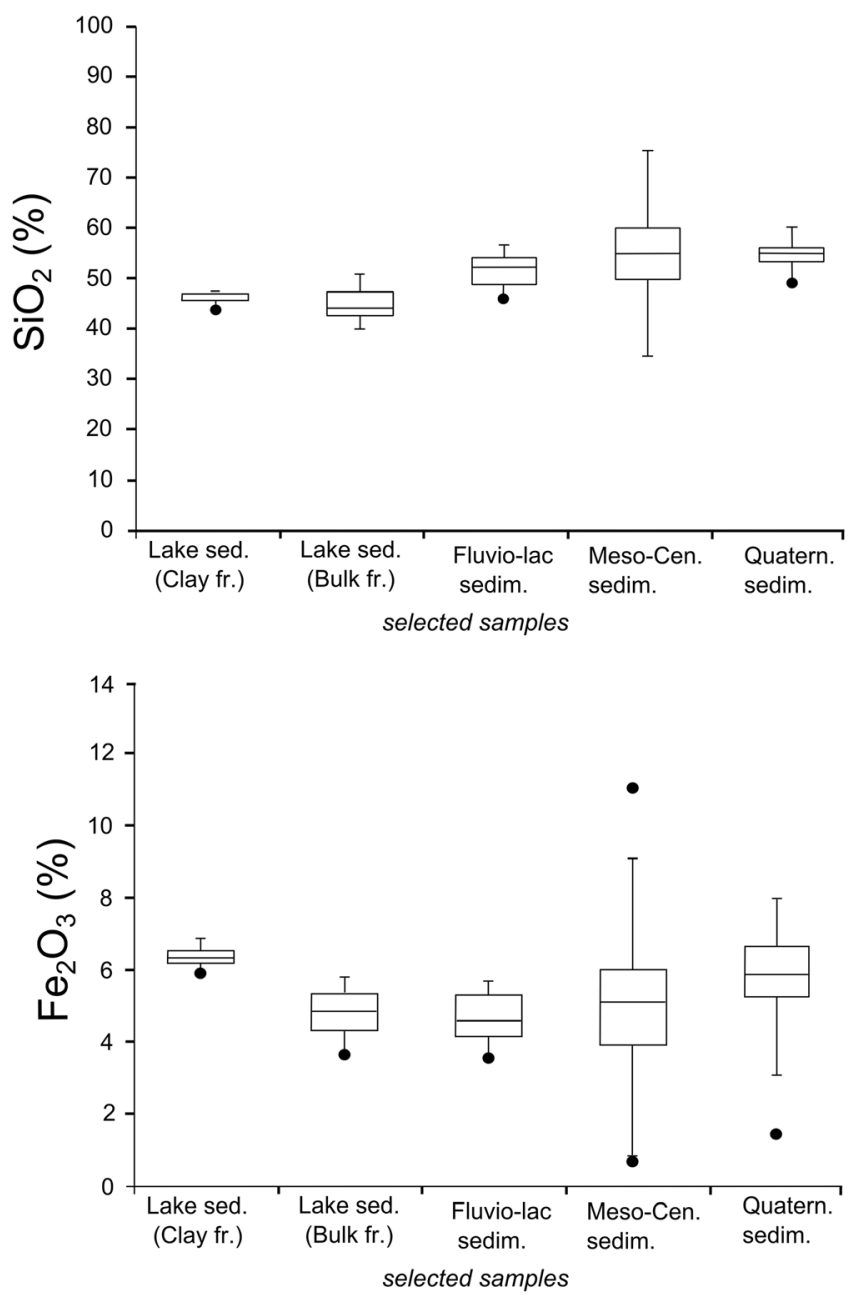

Fig. 6 Box-and-whisker plots for major elements in the analyzed samples. The horizontal bar in the box refers to the median value; the ends of the whiskers are the maximum and minimum values of variables; lower quartiles) has been obtained. IQR is a measure of variability, based on dividing a data set into quartiles. Finally, outlier values (data point that differs significantly from other values) has been calculated and reported into the box-andwhiskers plot.

\section{Enrichment factors}

In order to evaluate the possible contamination of the analyzed samples, the enrichment factors (EFs) for metals of environmental interest were calculated.

In the present study, the EFs were calculated using the UCC (upper continental crust, McLennan et al. 2006) and local bedrock compositions as reference standards. The used equations are as follows (Reimann and De Caritat 2005):

(i) $\mathrm{EF}$ respect to $\mathrm{UCC}=(X / \mathrm{Ti})_{\text {sample }} /(X / \mathrm{Ti})_{\mathrm{UCC}}$

(ii) $\mathrm{EF}$ respect to local bedrock $=(X / \mathrm{Ti})_{\text {sample }} /(X / \mathrm{Ti})_{\text {loc.bed. }}$
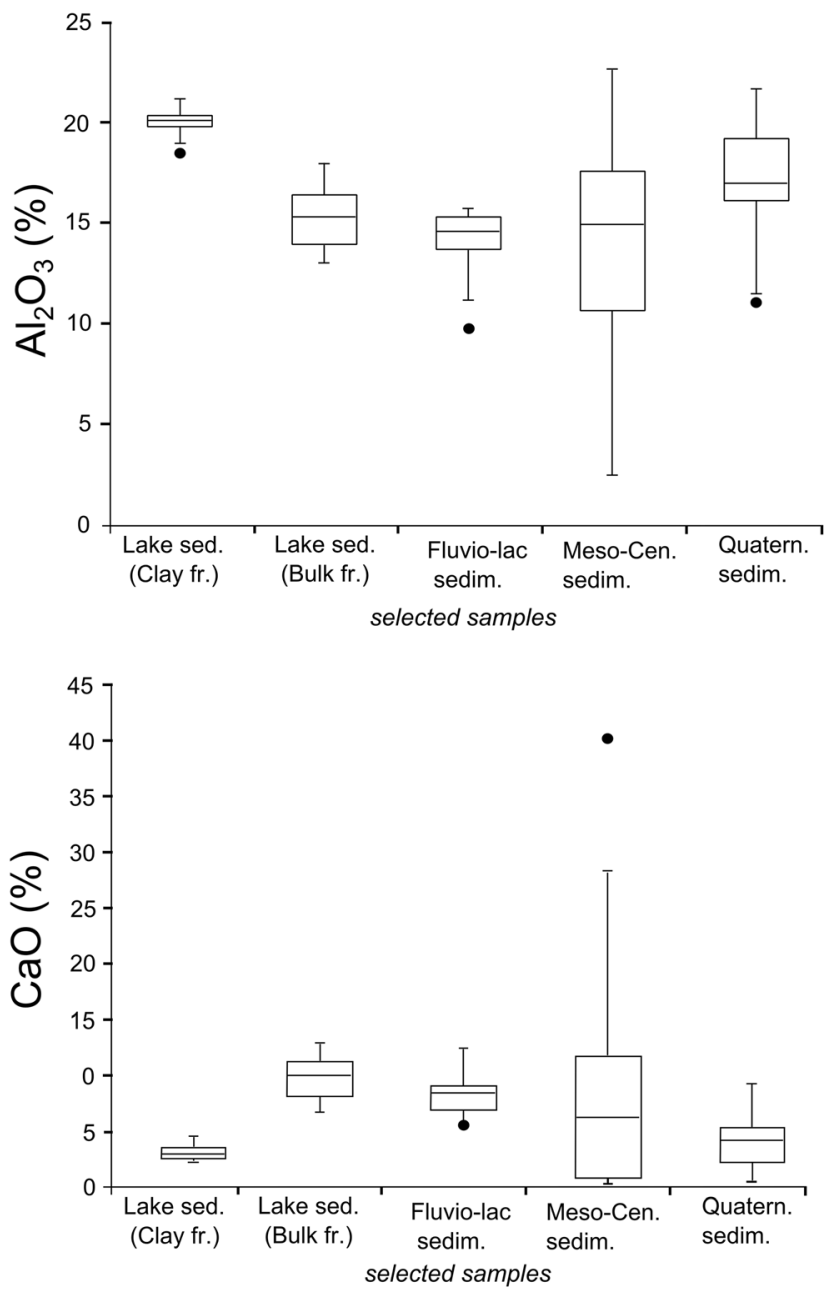

the top and bottom of the boxes are the values of first and third quartiles; dark circles represent the outliers values of the dataset 
where $X$ and Ti are the weight percentages of a given element and titanium, respectively.

Titanium was used as a normalizing element because it is associated with crustal rock sources and it is characterized by negligible mobility during weathering and diagenesis (e.g., Mongelli et al. 2014b and references therein). Five categories for the EF index are recognized as follows (Sutherland 2000): $\mathrm{EF}<2$ is depletion to minimal enrichment, EF 2-5 is moderate enrichment, EF 5-20 is significant enrichment, and EF 2040 is extremely high enrichment.

\section{Results}

\section{Mineralogy}

Results of mineralogical analyses are presented in Table 2.
Mineralogical phases were determined based on relative intensity of higher peaks. The most abundant mineralogical phases detected in the analyzed samples are mainly quartz and calcite. The other mineralogical phases are feldspars, muscovite/illite, interstratified clay minerals, and chlorite. Dolomite is present only in three fluvio-lacustrine samples.

\section{Fluvio-lacustrine samples}

In the quaternary fluvio-lacustrine deposits, quartz reaches maximum values in sample EFF2 $(42.80 \%)$ and shows a median of $34.29 \%$. Calcite ranges from 18.59 to $42.78 \%$ with a median of $29.31 \%$. Feldspars (median $=7.76 \%$ ) and chlorite (median $=8.38 \%$ ) show quite similar abundances in all fluviolacustrine samples. Finally, muscovite/illite median is $18.40 \%$ with a range from 14.84 to $29.59 \%$.

Table 2 Mineralogical composition (in percentage) of lake and fluvio-lacustrine samples

\begin{tabular}{|c|c|c|c|c|c|c|c|}
\hline & Quartz (\%) & Calcite (\%) & Feldspar (\%) & Muscovite/illite (\%) & Chlorite (\%) & Interstr. clay $(\%)$ & Dolomite (\%) \\
\hline \multicolumn{8}{|c|}{ Lake sediments } \\
\hline F1 3 & 23.5 & 23.5 & 7.0 & 10.5 & 4.7 & 11.1 & 19.5 \\
\hline F1 6 & 25.4 & 27.5 & 4.7 & 10.3 & 10.7 & 12.0 & 9.2 \\
\hline F1 12 & 27.2 & 20.7 & 5.4 & 10.5 & 13.9 & 11.4 & 10.6 \\
\hline R9 & 27.3 & 25.5 & 7.1 & 12.5 & 13.4 & 14.0 & nd \\
\hline $\mathrm{R} 12$ & 26.2 & 27.4 & 7.5 & 13.7 & 10.9 & 14.0 & nd \\
\hline $\mathrm{R} 18$ & 28.1 & 22.3 & 7.9 & 14.6 & 12.3 & 14.4 & nd \\
\hline $\mathrm{T} 1$ & 29.5 & 19.0 & 8.2 & 12.7 & 13.5 & 16.9 & nd \\
\hline $\mathrm{c} / \mathrm{T}$ & 30.4 & 52.2 & 7.3 & 5.2 & 4.7 & nd & nd \\
\hline $\mathrm{a} / \mathrm{V}$ & 37.2 & 44.8 & 6.0 & 5.6 & 6.2 & nd & nd \\
\hline $\mathrm{b} / \mathrm{V}$ & 32.2 & 50.0 & 6.2 & 5.9 & 5.5 & nd & nd \\
\hline $\mathrm{c} / \mathrm{V}$ & 33.9 & 47.2 & 5.5 & 6.8 & 6.3 & nd & nd \\
\hline $\mathrm{d} / \mathrm{V}$ & 30.6 & 51.1 & 5.6 & 6.5 & 6.1 & nd & nd \\
\hline $\mathrm{V} 3$ & 31.4 & 51.0 & 7.0 & 5.0 & 5.3 & nd & nd \\
\hline \multicolumn{8}{|c|}{ Fluvio-lacustrine sedim. } \\
\hline EFF1 & 40.0 & 20.2 & 7.1 & 16.8 & 15.6 & nd & nd \\
\hline EFF2 & 42.8 & 18.5 & 8.8 & 16.5 & 13.1 & nd & nd \\
\hline EFF3 & 39.3 & 21.1 & 7.2 & 20.7 & 11.5 & nd & nd \\
\hline EFF4 & 36.5 & 36.9 & 5.7 & 14.8 & 5.8 & nd & nd \\
\hline EFF5 & 30.3 & 38.1 & 7.9 & 15.8 & 7.6 & nd & nd \\
\hline EFF6 & 27.4 & 35.8 & 5.2 & 21.7 & 9.7 & nd & nd \\
\hline EFF7 & 34.1 & 30.8 & 6.9 & 18.8 & 9.2 & nd & nd \\
\hline EFF8 & 30.0 & 24.9 & 12.6 & 25.2 & 7.1 & nd & nd \\
\hline EFF9 & 34.4 & 32.5 & 8.8 & 17.2 & 7.0 & nd & nd \\
\hline EFF10 & 37.9 & 24.5 & 10.0 & 18.8 & 8.7 & nd & nd \\
\hline EFF11 & 35.4 & 30.1 & 8.4 & 17.9 & 8.0 & nd & nd \\
\hline EFF12 & 27.5 & 42.7 & 7.3 & 15.2 & 7.0 & nd & nd \\
\hline EFF13 & 28.2 & 28.4 & 11.2 & 24.2 & 7.7 & nd & nd \\
\hline EFF14 & 30.4 & 22.8 & 7.5 & 29.5 & 9.5 & nd & nd \\
\hline
\end{tabular}

nd: not detected 
The relative abundance of quartz and calcite, which are the main mineralogical phases, is variable for lacustrine samples (Fig. 5a, b). In the F core, quartz shows a median value of $25.38 \%$ while calcite has a median of $23.92 \%$. In the R core, quartz $($ median $=27.25 \%)$ and calcite $($ median $=25.2 \%)$ show very similar values. In the $\mathrm{T}$ core, quartz has a median of $29.98 \%$ while calcite shows a median of $35.66 \%$. In the $\mathrm{V}$ core, calcite abundance is higher with respect to quartz with median values of $48.85 \%$ and $33.11 \%$, respectively.

\section{Lake sediments}

For all lake samples, feldspars display quite similar values with a median of $7.05 \%$, a minimum of $4.73 \%$ and a maximum of $8.21 \%$.

Muscovite/illite present a median values of $10.23 \%$ ranging from 5.04 to $14.69 \%$, and they show maximum values in core $\mathrm{R}(\max =13.74 \%)$ and minimum value in core $\mathrm{V}$ (5.04\%).

Chlorite $($ median $=6.39 \%, \min =4.70, \max =13.96 \%)$ is higher in core $\mathrm{F}($ median $=10.75), \mathrm{R}($ median $=12.36)$, and $\mathrm{T}$ (median $=9.10 \%$ ) while is less abundant in core V (median $=6.11)$.

Interstratified clay minerals are present only in cores $\mathrm{F}, \mathrm{R}$, and $\mathrm{T}$, and this mineralogical phase presents a median of $14.05 \%$, maximum value of $16.95 \%$, and a minimum of $9.21 \%$.

Dolomite is present in the core $\mathrm{F}$ only showing a minimum of $9.21 \%$, a maximum of $19.50 \%$, and a median of $10.63 \%$.

\section{Geochemistry}

The most abundant major oxides are $\mathrm{SiO}_{2}$ and $\mathrm{Al}_{2} \mathrm{O}_{3}$ usually followed by $\mathrm{Fe}_{2} \mathrm{O}_{3}$ and $\mathrm{CaO}$ (Table 3, Fig.6).

\section{Lake sediments (bulk fraction)}

In the bulk fraction of lacustrine samples, $\mathrm{SiO}_{2}$ shows a median of $44.17 \%$ and values which ranges from 39.88 to $50.82 \% ; \mathrm{Al}_{2} \mathrm{O}_{3}$ ranges from 12.93 to $17.94 \%$ with a median of $15.26 . \mathrm{Fe}_{2} \mathrm{O}_{3}$ has median values of $5.39 \%(\mathrm{~min}=4.18 \%$, $\max =6.34 \%$ ) while $\mathrm{CaO}$ content $($ median $=9.84 \%)$ varies from a minimum of 6.58 to a maximum of $12.72 \%$. TOC in lacustrine sediments shows quite similar values, with a median value of $6.62 \%$ ranging from a minimum of 4.82 (sample R9) to a maximum of $9.79 \%$ (sample $\mathrm{c} / \mathrm{t}$ ).

$\mathrm{V}(\mathrm{med}=114 \mathrm{ppm}), \mathrm{Cr}(\mathrm{med}=100 \mathrm{ppm})$, and $\mathrm{Zn}$ (median $=110 \mathrm{ppm}$ ) are the most abundant trace elements with the higher variability values. $\mathrm{Cu}(\mathrm{med}=50 \mathrm{ppm})$ and Ni (median $=40 \mathrm{ppm}$ ) show very similar median values and IQR values. $\mathrm{Pb}$ ranges from 21 to $35 \mathrm{ppm}$ with a median value of 24 ppm. Minor abundances were observed for $\mathrm{Co}$ (median = $13 \mathrm{ppm}$ ) and As (median $=8 \mathrm{ppm}$ ) with very lower range values of 5 and $6 \mathrm{ppm}$ respectively. La (median = $39.2 \mathrm{ppm}), \mathrm{Ce}($ median $=78.5 \mathrm{ppm})$, and $\mathrm{Nd}($ median $=$ $32.6 \mathrm{ppm}$ ) display always the REE higher concentrations. $(\mathrm{La} / \mathrm{Yb})_{\mathrm{REE}}$ median is 1.19 and it has not been observed fractionation between HREEs and LREEs.

\section{Lake sediments (clay fraction)}

In the clay fraction of lacustrine samples, $\mathrm{SiO}_{2}$ has a median of $46.18 \%$ ranging from 43.81 to $47.53 \% ; \mathrm{Al}_{2} \mathrm{O}_{3}$ varies from 18.38 to $21.3 \%$ with a median of $20.01 \%$. The median value of $\mathrm{Fe}_{2} \mathrm{O}_{3}$ is $6.87 \%(\mathrm{~min}=6.47 \%$; $\max =7.42 \%)$ while $\mathrm{CaO}$ (median $=2.78 \%)$ ranges from $2.06(\min )$ to $4.4 \%(\max )$.

Concerning trace elements, $\mathrm{V}($ median $=154 \mathrm{ppm}), \mathrm{Cr}$ $($ median $=120 \mathrm{ppm})$, and $\mathrm{Zn}($ median $=150)$ display higher concentrations in clay fraction $(<2 \mu)$ of lacustrine sediment samples. $\mathrm{Pb}($ median $=42 \mathrm{ppm}), \mathrm{Cu}($ median $=40)$, and $\mathrm{Ni}$ (median $=50)$ show similar median. Lower element enrichment quantities were observed for Co and As which show median values respectively of 16 and 4 ppm (less abundant element) and the same lower range value $(\mathrm{IQR}=5)$. As it has been observed for bulk fraction, $\mathrm{La}, \mathrm{Ce}$, and $\mathrm{Nd}$ are the most abundant REE elements and they show median values of 53.7 ppm, 105 ppm, and 53.2 ppm, respectively. Among all the analyzed samples, these sediments display a moderate HREE/LREE fractionation with a $(\mathrm{La} / \mathrm{Yb})_{\mathrm{UCC}}$ median value of 1.38 .

\section{Fluvio-lacustrine samples}

In the fluvio-lacustrine samples, $\mathrm{SiO}_{2}$ has a minimum of $47.04 \%$ and a maximum $56.51 \%$ with a median of $52.19 \%$. $\mathrm{Al}_{2} \mathrm{O}_{3}$ ranges from 9.7 to $15.65 \%$ (median of $14.53 \%$ ) while $\mathrm{Fe}_{2} \mathrm{O}_{3}$ has a median value of $5.11 \%$ with a range from 2.91 to $6.22 \%$. The median value of $\mathrm{CaO}$ is $8.2 \%$, the minimum is $5.42 \%$ while the minimum is $12.87 \%$.

As concern trace elements in fluvio-lacustrine samples, $\mathrm{Zn}$ (med $=141 \mathrm{ppm})$ is the most concentrated element followed by $\mathrm{V}(\mathrm{med}=104 \mathrm{ppm}), \mathrm{Cr}($ median $=62 \mathrm{ppm}), \mathrm{Ni}($ median $=$ $47.6 \mathrm{ppm}), \mathrm{Cu}($ median $=30 \mathrm{ppm})$, and $\mathrm{Pb}($ median $=$ $23 \mathrm{ppm}$ ). Lower concentrations and range values for Co (median $=12 \mathrm{ppm}$ ) and As (median =6.85) were observed. Also for these samples $\mathrm{La}, \mathrm{Ce}$, and $\mathrm{Nd}$ are the most abundant REEs showing median values of $40.05 \mathrm{ppm}, 77.95 \mathrm{ppm}$, and $34.3 \mathrm{ppm}$, respectively. The $(\mathrm{La} / \mathrm{Yb})_{\mathrm{UCC}}$ ratio has a median of 1.03 which reflecting no HREE/LREE fractionation.

\section{Meso-Cenozoic sediments}

In the twenty-seven Meso-Cenozoic lithoid samples, $\mathrm{SiO}_{2}$ shows a range from 16.42 (Albidona fm.) to $90.93 \%$ (Gorgoglione fm.) with a median of $55 \%$. Among the different sampled formations, the abundances of $\mathrm{SiO}_{2}$ are the main 
Table 3 Major oxides, selected trace elements, and REE values in the collected samples. The median value is displayed

\begin{tabular}{|c|c|c|c|c|c|c|c|c|c|c|c|c|c|}
\hline & $\mathrm{SiO}_{2}$ & $\mathrm{Al}_{2} \mathrm{O}_{3}$ & $\mathrm{Fe}_{2} \mathrm{O}_{3}$ & $\mathrm{CaO}$ & $\mathrm{V}$ & $\mathrm{Pb}$ & $\mathrm{Cr}$ & Co & $\mathrm{Ni}$ & $\mathrm{Cu}$ & $\mathrm{Zn}$ & As & $\sum \mathrm{REE}$ \\
\hline Units & $\%$ & $\%$ & $\%$ & $\%$ & ppm & ppm & ppm & ppm & ppm & ppm & ppm & ppm & ppm \\
\hline d.1. & 0.01 & 0.01 & 0.01 & 0.01 & 5 & 5 & 20 & 1 & 20 & 10 & 30 & 5 & \\
\hline \multicolumn{14}{|c|}{ Lacustrine sediments (clay fraction) } \\
\hline F1 3 & 45.7 & 18.5 & 6.5 & 3.6 & 144 & 42 & 110 & 15 & 50 & 50 & 160 & 10 & 222 \\
\hline F1 6 & 43.8 & 19.7 & 6.4 & 4.4 & 148 & 44 & 120 & 15 & 50 & 50 & 150 & 8 & 221 \\
\hline F1 12 & 47.5 & 21.3 & 7.4 & 2.4 & 164 & 46 & 130 & 20 & 60 & 60 & 140 & 8 & 255 \\
\hline $\mathrm{a} / \mathrm{R}$ & 46.9 & 19.8 & 7.1 & 2.0 & 154 & 43 & 120 & 17 & 60 & 70 & 220 & 10 & 298 \\
\hline R9 & 45.8 & 20.2 & 6.8 & 2.7 & 162 & 43 & 130 & 15 & 50 & 50 & 150 & 8 & 231 \\
\hline R12 & 45.3 & 20.0 & 7.1 & 2.9 & 159 & 43 & 130 & 15 & 50 & 60 & 160 & 8 & 219 \\
\hline R18 & 46.7 & 20.0 & 6.9 & 3.5 & 158 & 35 & 130 & 15 & 50 & 50 & 150 & $<5$ & 235 \\
\hline $\mathrm{T} 1$ & 45.8 & 20.5 & 6.9 & 2.5 & 157 & 38 & 130 & 16 & 50 & 50 & 140 & 7 & 243 \\
\hline $\mathrm{a} / \mathrm{T}$ & 44.5 & 19.2 & 6.7 & 3.6 & 145 & 34 & 120 & 16 & 50 & 50 & 130 & 8 & 220 \\
\hline $\mathrm{c} / \mathrm{T}$ & 46.7 & 19.7 & 6.8 & 2.4 & 159 & 36 & 120 & 18 & 50 & 50 & 140 & 10 & 236 \\
\hline $\mathrm{a} / \mathrm{V}$ & 47.3 & 20.5 & 7.0 & 2.4 & 159 & 49 & 120 & 16 & 50 & 50 & 130 & 8 & 244 \\
\hline $\mathrm{b} / \mathrm{V}$ & 46.1 & 19.7 & 6.7 & 2.4 & 151 & 43 & 120 & 17 & 50 & 50 & 160 & 9 & 230 \\
\hline $\mathrm{c} / \mathrm{V}$ & 45.9 & 20.0 & 6.8 & 2.4 & 152 & 31 & 120 & 17 & 50 & 50 & 130 & 10 & 237 \\
\hline $\mathrm{d} / \mathrm{V}$ & 47.1 & 18.3 & 6.6 & 3.1 & 147 & 33 & 120 & 17 & 50 & 50 & 130 & 10 & 209 \\
\hline V3 & 46.6 & 20.3 & 7.1 & 2.8 & 153 & 42 & 120 & 16 & 50 & 50 & 150 & 9 & 241 \\
\hline Median & 46.1 & 20.0 & 6.8 & 2.7 & 154 & 42 & 120 & 16 & 50 & 50 & 150 & 8 & 235 \\
\hline \multicolumn{14}{|c|}{ Lacustrine sediments (bulk fraction) } \\
\hline F1 3-B & 47.5 & 12.9 & 4.5 & 9.8 & 91 & 22 & 80 & 13 & 30 & 40 & 100 & $<5$ & 172 \\
\hline F1 6-B & 41.6 & 13.8 & 4.8 & 12.7 & 105 & 23 & 90 & 13 & 40 & 40 & 110 & $<5$ & 179 \\
\hline F1 12-B & 50.2 & 14.1 & 4.9 & 8.1 & 102 & 25 & 90 & 15 & 40 & 40 & 100 & $<5$ & 185 \\
\hline $\mathrm{a} / \mathrm{R}-\mathrm{B}$ & 42.6 & 14.7 & 5.2 & 12.1 & 109 & 22 & 90 & 13 & 40 & 40 & 120 & $<5$ & 181 \\
\hline R9-B & 50.8 & 13.4 & 4.4 & 9.2 & 93 & 24 & 80 & 10 & 40 & 30 & 100 & $<5$ & 180 \\
\hline R12-B & 50.8 & 12.9 & 4.1 & 10.0 & 81 & 26 & 80 & 10 & 30 & 30 & 110 & $<5$ & 170 \\
\hline R18-B & 47.1 & 15.2 & 5.3 & 9.1 & 114 & 27 & 100 & 13 & 40 & 40 & 120 & $<5$ & 199 \\
\hline T1-B & 44.1 & 17.9 & 6.2 & 6.5 & 130 & 35 & 110 & 14 & 50 & 50 & 130 & 5 & 217 \\
\hline $\mathrm{a} / \mathrm{T}-\mathrm{B}$ & 42.6 & 15.5 & 5.5 & 10.4 & 120 & 21 & 90 & 13 & 40 & 40 & 110 & 9 & 189 \\
\hline $\mathrm{c} / \mathrm{T}-\mathrm{B}$ & 39.8 & 15.4 & 5.6 & 12.0 & 122 & 21 & 100 & 15 & 40 & 40 & 100 & 8 & 177 \\
\hline $\mathrm{a} / \mathrm{V}-\mathrm{B}$ & 43.6 & 17.7 & 6.3 & 7.5 & 137 & 27 & 110 & 15 & 50 & 50 & 140 & 7 & 218 \\
\hline $\mathrm{b} / \mathrm{V}-\mathrm{B}$ & 41.0 & 15.4 & 5.5 & 10.8 & 119 & 22 & 100 & 14 & 40 & 40 & 110 & 6 & 184 \\
\hline $\mathrm{c} / \mathrm{V}-\mathrm{B}$ & 44.4 & 17.4 & 6.1 & 7.7 & 135 & 25 & 110 & 14 & 40 & 50 & 120 & 7 & 207 \\
\hline $\mathrm{d} / \mathrm{V}-\mathrm{B}$ & 43.5 & 13.8 & 5.0 & 11.5 & 107 & 22 & 100 & 12 & 50 & 40 & 100 & $<5$ & 169 \\
\hline V3-B & 45.3 & 17.0 & 6.1 & 7.5 & 134 & 27 & 110 & 14 & 50 & 50 & 110 & $<5$ & 214 \\
\hline Median & 44.1 & 15.2 & 5.3 & 9.8 & 114 & 24 & 100 & 13 & 40 & 40 & 110 & 7 & 184 \\
\hline \multicolumn{14}{|c|}{ Fluvio-lacustrine sediments } \\
\hline EFF1 & 53.3 & 15.3 & 5.9 & 6.5 & 113 & 33 & 63 & 14 & 57 & 40 & 143 & 8 & 188 \\
\hline EFF2 & 54.2 & 15.2 & 5.8 & 6.0 & 113 & 25 & 78 & 13 & 59 & 30 & 140 & 7 & 194 \\
\hline EFF3 & 54.2 & 15.6 & 5.9 & 5.4 & 119 & 21 & 73 & 17 & 60 & 50 & 141 & 7 & 195 \\
\hline EFF4 & 53.4 & 12.7 & 4.4 & 8.6 & 92 & 22 & 59 & 11 & 43 & 30 & 106 & 7 & 183 \\
\hline EFF5 & 48.6 & 14.9 & 6.2 & 9.4 & 111 & 52 & 64 & 16 & 58 & 40 & 153 & 9 & 213 \\
\hline EFF6 & 47.0 & 15.4 & 5.5 & 9.6 & 117 & 22 & 102 & 13 & 49 & 30 & 133 & 6 & 187 \\
\hline EFF7B & 48.0 & 15.2 & 5.0 & 9.0 & 114 & 18 & 62 & 12 & 48 & 40 & 141 & 5 & 196 \\
\hline EFF8 & 48.8 & 13.1 & 4.5 & 8.0 & 93 & 23 & 83 & 10 & 43 & 40 & 209 & 6 & 171 \\
\hline EFF9B & 48.6 & 12.4 & 4.1 & 8.4 & 86 & 26 & 58 & 9 & 42 & 40 & 180 & 6 & 171 \\
\hline EFF10 & 56.5 & 14.1 & 4.6 & 5.5 & 102 & 30 & 55 & 10 & 47 & 30 & 147 & 6 & 188 \\
\hline EFF11 & 50.2 & 14.0 & 4.7 & 7.7 & 96 & 17 & 61 & 10 & 43 & 30 & 129 & 4 & 188 \\
\hline EFF12B & 54.0 & 9.7 & & 12.8 & 58 & 14 & 46 & 7 & 31 & 20 & 85 & 3 & 137 \\
\hline
\end{tabular}


Table 3 (continued)

\begin{tabular}{|c|c|c|c|c|c|c|c|c|c|c|c|c|c|}
\hline & $\mathrm{SiO}_{2}$ & $\mathrm{Al}_{2} \mathrm{O}_{3}$ & $\mathrm{Fe}_{2} \mathrm{O}_{3}$ & $\mathrm{CaO}$ & $\mathrm{V}$ & $\mathrm{Pb}$ & $\mathrm{Cr}$ & Co & $\mathrm{Ni}$ & $\mathrm{Cu}$ & $\mathrm{Zn}$ & As & $\sum \mathrm{REE}$ \\
\hline EFF13 & 51.0 & 14.3 & 5.1 & 8.8 & 103 & 23 & 63 & 12 & 45 & 30 & 129 & 4 & 174 \\
\hline EFF14 & 54.2 & 14.7 & 5.7 & 6.9 & 105 & 43 & 58 & 14 & 50 & 30 & 149 & 7 & 186 \\
\hline Median & 52.1 & 14.5 & 5.1 & 8.2 & 104 & 23 & 62 & 12 & 47 & 30 & 141 & 6 & 188 \\
\hline \multicolumn{14}{|c|}{ Meso-Cenozoic samples } \\
\hline \multicolumn{14}{|c|}{ Moliterno succession } \\
\hline EF1 & 74.6 & 10.9 & 2.9 & 1.8 & 84 & 6 & 60 & 20 & 60 & 50 & 30 & 5 & 152 \\
\hline EF5 & 55.4 & 15.0 & 5.6 & 7.4 & 108 & 16 & 80 & 15 & 30 & 20 & 90 & 7 & 188 \\
\hline EF6 & 58.8 & 18.1 & 7.9 & 1.1 & 93 & 21 & 90 & 12 & 30 & 40 & 80 & 8 & 223 \\
\hline EF81 & 61.0 & 19.3 & 6.2 & 0.1 & 139 & 8 & 100 & 14 & 40 & 30 & 100 & 5 & 176 \\
\hline EF82 & 56.2 & 20.6 & 7.4 & 0.3 & 137 & 21 & 110 & 17 & 40 & 30 & 110 & 5 & 184 \\
\hline \multicolumn{14}{|c|}{ Albidona Flysch } \\
\hline EF16 & 48.3 & 14.6 & 4.4 & 11.5 & 119 & 23 & 90 & 13 & 40 & 50 & 110 & 5 & 200 \\
\hline EF79 & 20.3 & 5.3 & 2.0 & 38.0 & 52 & 6 & 50 & 13 & 40 & 40 & 50 & 5 & 262 \\
\hline EF84 & 17.7 & 4.7 & 1.7 & 39.3 & 50 & 6 & 50 & 9 & 40 & 30 & 50 & 5 & 214 \\
\hline EF57 & 41.4 & 12.5 & 4.5 & 18.7 & 101 & 18 & 70 & 8 & 37 & 40 & 90 & 5 & 178 \\
\hline EF91 & 16.4 & 4.3 & 1.7 & 40.9 & 46 & 6 & 40 & 8 & 30 & 30 & 40 & 5 & 150 \\
\hline \multicolumn{14}{|c|}{ Gorgoglione Flysch } \\
\hline EF22 & 55.0 & 14.4 & 5.2 & 6.6 & 108 & 25 & 50 & 12 & 20 & 20 & 100 & 8 & 164 \\
\hline EF26 & 51.1 & 16.9 & 5.4 & 6.4 & 137 & 24 & 100. & 13 & 30 & 30 & 110 & 7 & 205 \\
\hline EF83 & 90.9 & 2.4 & 1.2 & 0.9 & 20 & 5 & 20 & 7 & 20 & 30 & 30 & 5 & 150 \\
\hline EF78 & 49.0 & 15.1 & 5.3 & 11.1 & 116 & 23 & 80 & 9 & 30 & 30 & 110 & 6 & 184 \\
\hline EF 59 & 56.7 & 16.9 & 6.4 & 11.6 & 125 & 17 & 110 & 13 & 53 & 30 & 100 & 5 & 85 \\
\hline \multicolumn{14}{|c|}{ Galestri fm. } \\
\hline EF28 & 50.8 & 22.0 & 11.5 & 0.1 & 157 & 26 & 120 & 50 & 50 & 30 & 140 & 10 & 221 \\
\hline EF30 & 58.5 & 19.5 & 6.3 & 0.2 & 135 & 21 & 110 & 35 & 50 & 50 & 140 & 5 & 223 \\
\hline EF76 & 64.0 & 14.8 & 7.8 & 0.8 & 107 & 14 & 70 & 21 & 70 & 110 & 60 & 5 & 215 \\
\hline EF77 & 50.5 & 10.2 & 4.1 & 15.8 & 96 & 10 & 50 & 8 & 50 & 90 & 60 & 5 & 28 \\
\hline EF88 & 66.4 & 14.2 & 7.3 & 0.2 & 117 & 6 & 100 & 22 & 100 & 50 & 110 & 5 & 76 \\
\hline EF89 & 38.7 & 9.7 & 6.4 & 20.6 & 87 & 5 & 70 & 15 & 40 & 10 & 100 & 5 & 142 \\
\hline \multicolumn{14}{|c|}{ Scisti silicei } \\
\hline EF80 & 53.1 & 22.5 & 7.8 & 1.4 & 168 & 22 & 110 & 20 & 40 & 40 & 120 & 18 & 157 \\
\hline EF85 & 75.0 & 9.0 & 6.0 & 0.1 & 59 & 11 & 60 & 8 & 40 & 30 & 50 & 5 & 241 \\
\hline EF90 & 69.4 & 12.3 & 5.6 & 0.2 & 74 & 8 & 60 & 18 & 80 & 60 & 70 & 5 & 150 \\
\hline \multicolumn{14}{|c|}{ Ligurian complex } \\
\hline EF86 & 55.4 & 16.3 & 4.9 & 6.8 & 163 & 9 & 100 & 17 & 40 & 30 & 90 & 5 & 120 \\
\hline EF87 & 52.2 & 21.3 & 6.6 & 2.4 & 154 & 13 & 110 & 20 & 40 & 90 & 110 & 9 & 216 \\
\hline \multicolumn{14}{|c|}{ Monte Facito fm. } \\
\hline EF34 & 54.4 & 15.9 & 6.4 & 6.1 & 115 & 15 & 80 & 16 & 40 & 20 & 100 & 5 & 71 \\
\hline \multicolumn{14}{|c|}{ Quaternary sediments } \\
\hline EF 39 & 54.6 & 17.0 & 6.5 & 4.0 & 126 & 34 & 100 & 20 & 48 & 40 & 110 & 9 & 211 \\
\hline EF 41 & 55.7 & 16.5 & 6.1 & 5.1 & 127 & 64 & 90 & 19 & 49 & 40 & 120 & 9 & 204 \\
\hline EF 49 & 55.1 & 20.1 & 7.4 & 0.4 & 147 & 60 & 100 & 18 & 63 & 50 & 140 & 10 & 273 \\
\hline EF 50 & 62.3 & 16.8 & 6.2 & 0.3 & 122 & 43 & 60 & 18 & 35 & 20 & 90 & 15 & 307 \\
\hline EF 51 & 56.1 & 15.9 & 4.8 & 5.8 & 117 & 23 & 90 & 8 & 38 & 20 & 100 & 5 & 190 \\
\hline EF 52 & 69.1 & 10.9 & 1.9 & 5.1 & 51 & 19 & 40 & 4 & 17 & 10 & 40 & 5 & 189 \\
\hline EF 54 & 49.9 & 13.9 & 8.5 & 9.0 & 130 & 79 & 80 & 27 & 55 & 70 & 150 & 26 & 164 \\
\hline EF 60 & 54.9 & 14.2 & 4.9 & 7.4 & 107 & 23 & 80 & 15 & 44 & 40 & 100 & 5 & 176 \\
\hline EF 61 & 52.5 & 21.5 & 5.3 & 1.1 & 176 & 30 & 120 & 12 & 47 & 50 & 130 & 10 & 284 \\
\hline EF62 & 53.3 & 18.8 & 7.5 & 2.9 & 149 & 50 & 110 & 21 & 40 & 50 & 130 & 12 & 216 \\
\hline
\end{tabular}


Table 3 (continued)

\begin{tabular}{rlllllllllllll}
\hline & $\mathrm{SiO}_{2}$ & $\mathrm{Al}_{2} \mathrm{O}_{3}$ & $\mathrm{Fe}_{2} \mathrm{O}_{3}$ & $\mathrm{CaO}$ & $\mathrm{V}$ & $\mathrm{Pb}$ & $\mathrm{Cr}$ & $\mathrm{Co}$ & $\mathrm{Ni}$ & $\mathrm{Cu}$ & $\mathrm{Zn}$ & $\mathrm{As}$ & $\sum \mathrm{REE}$ \\
\hline EF63 & 58.6 & 16.5 & 6.4 & 3.1 & 127 & 23 & 100 & 16 & 40 & 40 & 110 & 7 & 191 \\
$\mathrm{EF} 65$ & 55.8 & 16.2 & 6.2 & 4.2 & 119 & 30 & 90 & 20 & 40 & 40 & 120 & 13 & 192 \\
EF67 & 52.4 & 19.4 & 7.4 & 3.2 & 153 & 30 & 110 & 20 & 50 & 50 & 120 & 10 & 243 \\
EF71 & 53.1 & 17.5 & 6.5 & 4.2 & 125 & 31 & 80 & 15 & 30 & 40 & 120 & 8 & 233 \\
EF74 & 53.3 & 21.0 & 7.0 & 1.2 & 159 & 32 & 110 & 19 & 40 & 50 & 130 & 10 & 262 \\
median & 54.9 & 16.8 & 6.4 & 4.0 & 127 & 31 & 90 & 18 & 40 & 40 & 120 & 10 & 211 \\
\hline
\end{tabular}

d.1.: detection limit

oxide and its distribution in the different lithologies is as follows: Moliterno succession $($ median $=58.86 \%$ ); Albidona $\mathrm{fm}$. $($ median $=20.32 \%)$; Gorgoglione fm. $($ median $=55 \%)$, Galestri formation (median $=54.74 \%$ ), and Scisti silicei $\mathrm{fm}$. $($ median $=69.49 \%)$; and Liguride fm. $($ median $=53.84 \%)$.

The distribution of $\mathrm{Al}_{2} \mathrm{O}_{3}$ shows a minimum of 2.44 (Gorgoglione fm.) and a maximum of $22.55 \%$ (Scisti silicei fm.) with a median of $14.88 \% ; \mathrm{Al}_{2} \mathrm{O}_{3}$ in the different formations is distributed as follows: Moliterno fm. (median = $18.10 \%$ ); Albidona fm. (median $=5.33 \%$ ); Gorgoglione fm. $($ median $=15.12 \%)$, Galestri fm. $($ median $=14.56 \%)$, and Scisti silicei fm. $($ median $=12.34 \%)$; and Liguride unit (median $=18.89 \%)$.

$\mathrm{Fe}_{2} \mathrm{O}_{3}$ has a median values of $5.65 \%$ ranging from 1.2 (Gorgoglione flysch) to $11.58 \%$ (Galestri formation). For each sampled formation, the abundances of $\mathrm{Fe}_{2} \mathrm{O}_{3}$ are the following: Moliterno succession (median $=6.2 \%$ ); Albidona Flysch $($ median $=2.03)$; Gorgoglione Flysch $($ median $=5.38 \%)$, Galestri formation $($ median $=6.9 \%$ ), and Scisti silicei (median $=6.01 \%)$; and Liguride complex (median $=5.8 \%)$.

$\mathrm{CaO}$ ranges from 0.13 (Albidona fm.) to $40.9 \%$ (Albidona fm.) and shows a median value of $6.13 \%$, and in the different formations, the abundances of $\mathrm{CaO}$ are as follows: Moliterno fm. $($ median $=1.16 \%)$; Albidona fm.$($ median $=38.08 \%)$; Gorgoglione $\mathrm{fm} .($ median $=6.64 \%)$, Galestri $\mathrm{fm} .($ median $=$ $0.58 \%)$, and Scisti silicei $\mathrm{fm}$. (median $=0.29 \%)$; and Liguride unit (median $=4.65 \%$ ).

In the Meso-Cenozoic bedrock samples, $\mathrm{V}$ (median = $108 \mathrm{ppm}), \mathrm{Cr}($ median $=80 \mathrm{ppm})$, and $\mathrm{Zn}($ median $=$ $100 \mathrm{ppm}$ ) are the most abundant trace elements, showing higher variability with respect to other elements. $\mathrm{Cu}$ (median $=$ $41.11 \mathrm{ppm}$ ) and $\mathrm{Ni}$ (median=43.73 ppm) display similar distribution and concentrations with the presence of two and one upper outliers, respectively. Lower concentrations and variability for $\mathrm{Co}($ median $=5 \mathrm{ppm})$, As $($ median $=14 \mathrm{ppm})$ and $\mathrm{Pb}($ median $=14 \mathrm{ppm})$ were observed. La (median $=$ $37.8 \mathrm{ppm}), \mathrm{Ce}($ median $=76.6 \mathrm{ppm})$, and $\mathrm{Nd}($ median $=$ $30.6 \mathrm{ppm}$ ) are the most abundant REEs. The median value of total REE ( $\left.\sum \mathrm{REE}\right)$ is $178.86 \mathrm{ppm}$; the $(\mathrm{La} / \mathrm{Yb})_{\mathrm{UCC}}$ ratio is 1.03 excluding a significant fractionation between HREEs and
LREEs. Among these samples three Ce-positive anomalies and three negative $\mathrm{Ce}$ anomalies have been observed.

\section{Quaternary sediments}

In the Quaternary silty-clayey samples, the range values of major oxides are 49.90 to $69.14 \%\left(\mathrm{SiO}_{2}\right), 10.98$ to $21.59 \%$ $\left(\mathrm{Al}_{2} \mathrm{O}_{3}\right), 1.98$ to $8.54 \%\left(\mathrm{Fe}_{2} \mathrm{O}_{3}\right)$, and $0.3 \%$ to $9.06 \%(\mathrm{CaO})$ while the median values are $54.93 \%, 16.89 \%, 6.41 \%$, and $4.01 \%$ respectively.

The most abundant trace elements are $\mathrm{V}$ (median $=$ $127 \mathrm{ppm}), \mathrm{Cr}($ median $=90 \mathrm{ppm})$, and $\mathrm{Zn}($ median $=$ $120 \mathrm{ppm}$ ) followed by $\mathrm{Pb}($ median $=31 \mathrm{ppm}), \mathrm{Cu}($ median $=$ $40 \mathrm{ppm}$ ), and $\mathrm{Ni}$ (median $=40 \mathrm{ppm})$. Lower concentrations and variability are related to $\mathrm{Co}(\mathrm{med}=18 \mathrm{ppm})$ and As (median $=10 \mathrm{ppm}$ ). The most abundant REEs are $\mathrm{La}, \mathrm{Ce}$, and $\mathrm{Nd}$ with median values of $43.4 \mathrm{ppm}, 90.8 \mathrm{ppm}$, and $36.7 \mathrm{ppm}$, respectively. ¿REE median is 211.87 . The $(\mathrm{La} / \mathrm{Yb})_{\mathrm{UCC}}$ ratio shows a median value of 1.00 thus excluding any HREE/ LREE fractionation.

\section{Enrichment factors (EFs)}

Enrichment factors were calculated, relatively to UCC (McLennan et al. 2006) and local bedrock, for all the studied samples (Table 4).

The calculation of the average composition of local bedrock was based on the average composition of the lithoid samples of the outcropping sampled formations (Table 5). The composition was weighted relatively of the areal extension of each sampled lithoid formation in the analyzed area. In this way, the average composition of the local bedrock of the area of interest has been calculated and, based on this, the enrichment factors were performed. No significant differences between UCC and local bedrock values has been observed; however, the local bedrock composition represent a more coherent and useful data for the trace elements behavior and their enrichment factors calculation. 
$\mid$

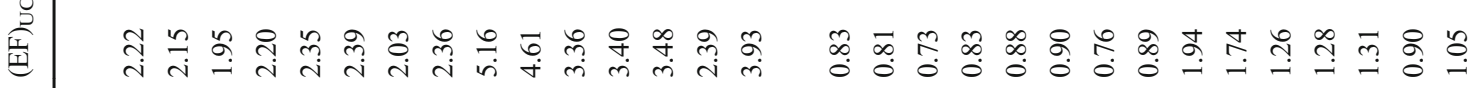

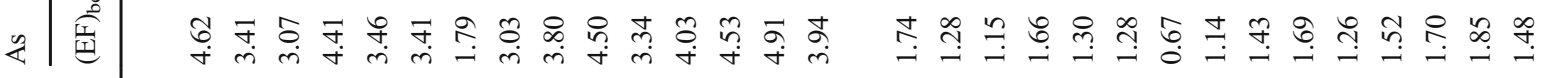

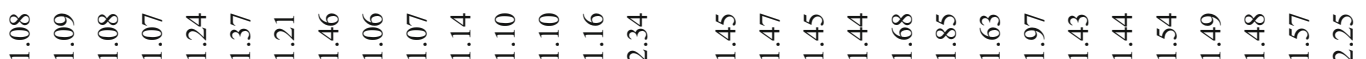

跑密

도은

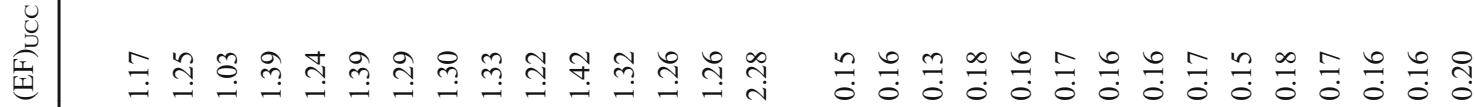

งี

总

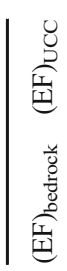

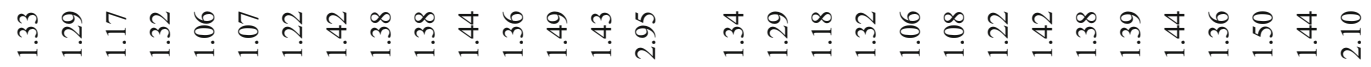

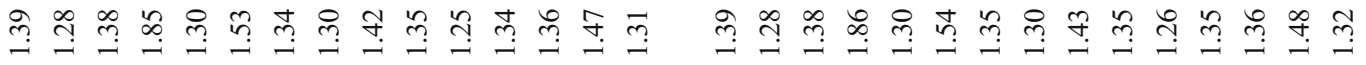

命

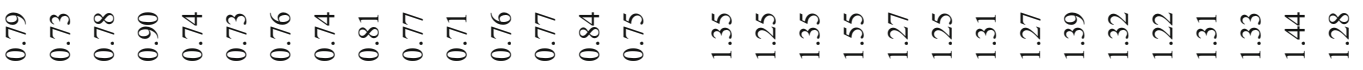

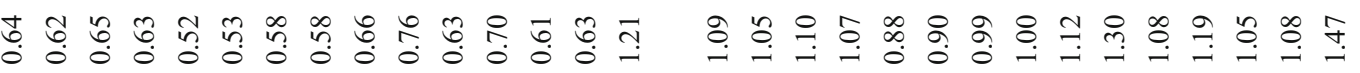

ঢ웅

\&

ลิ ลิ

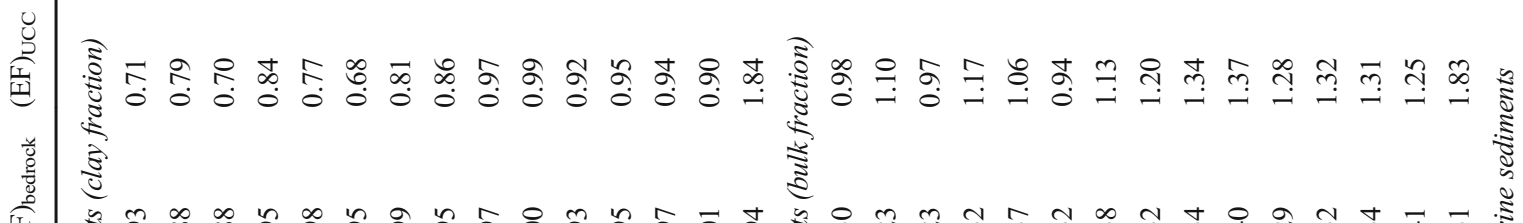
在

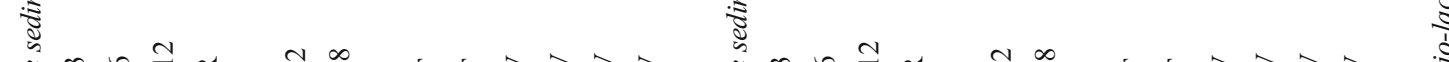

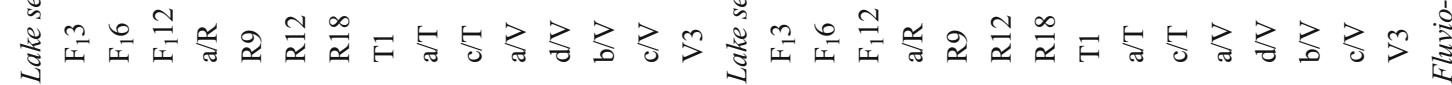




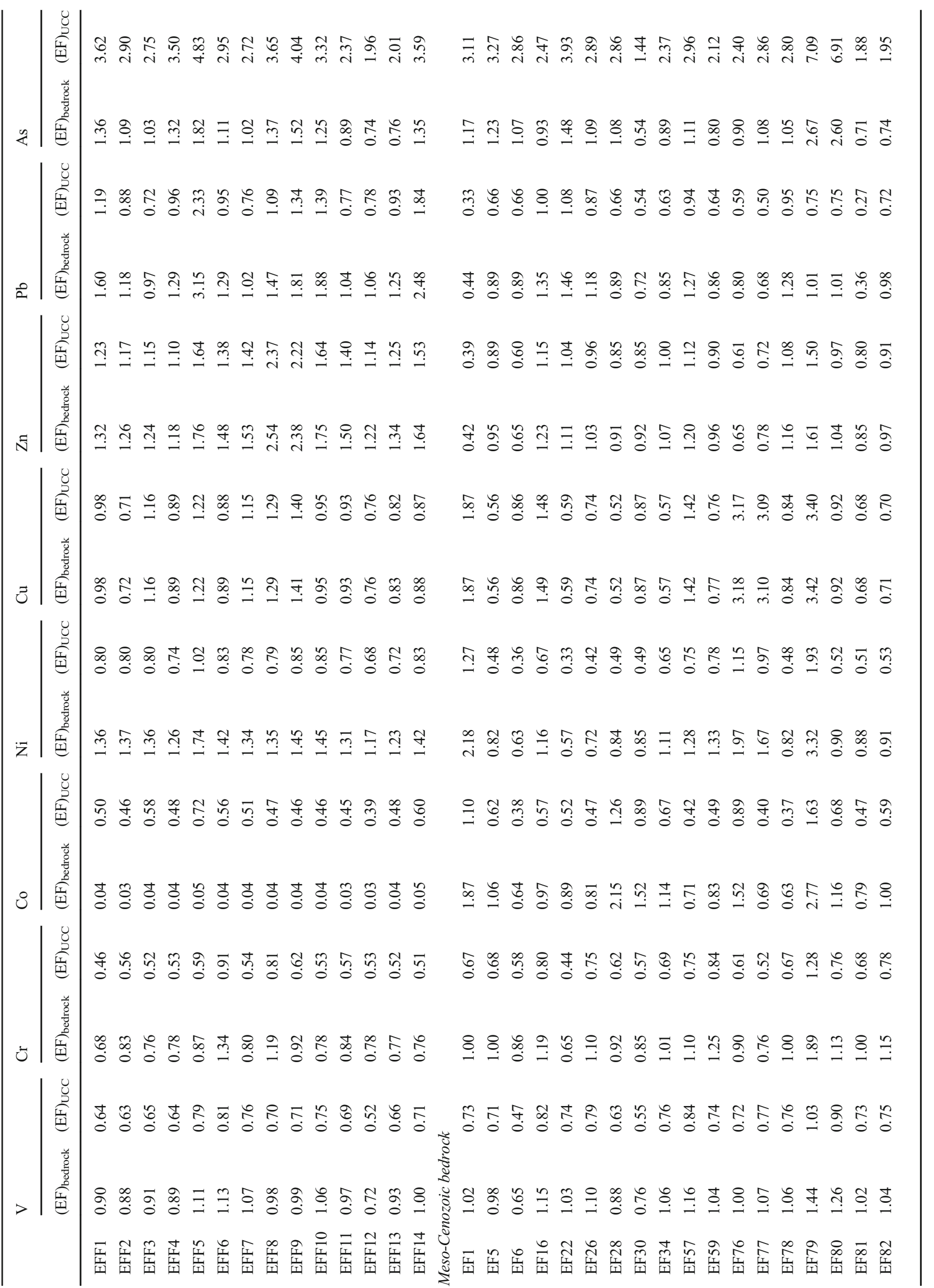




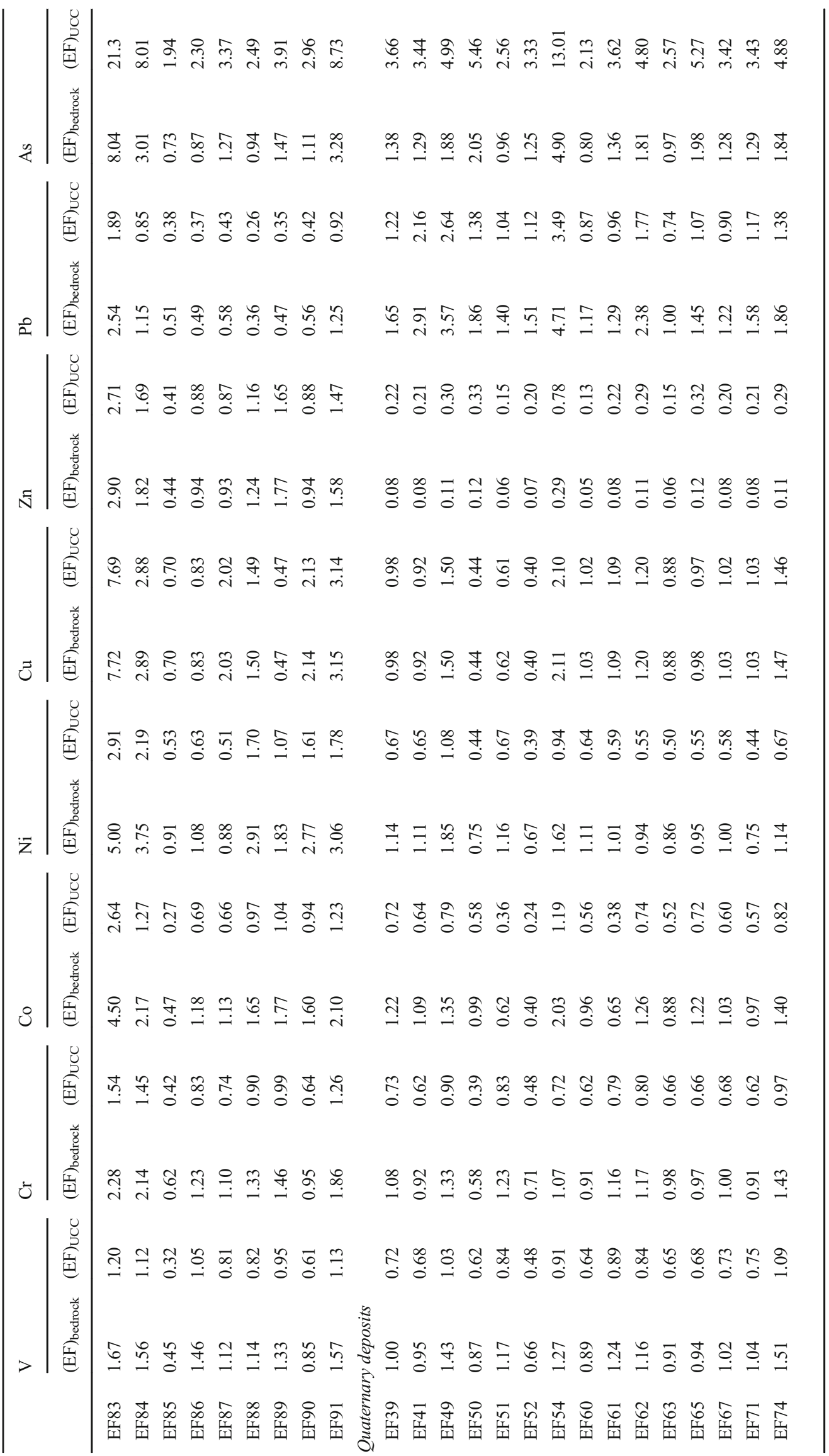


Table 5 Global UCC (McLennan et al. 2006) and local bedrock average composition (major oxides and trace elements)

\begin{tabular}{|c|c|c|c|c|c|c|c|c|c|c|c|c|}
\hline & $\begin{array}{l}\mathrm{SiO}_{2} \\
\%\end{array}$ & $\begin{array}{l}\mathrm{Al}_{2} 2 \mathrm{O}_{3} \\
\%\end{array}$ & $\begin{array}{l}\mathrm{Fe}_{2} \mathrm{O}_{3} \\
\%\end{array}$ & $\begin{array}{l}\mathrm{CaO} \\
\%\end{array}$ & $\begin{array}{l}\mathrm{V} \\
\mathrm{ppm}\end{array}$ & $\begin{array}{l}\mathrm{Pb} \\
\mathrm{ppm}\end{array}$ & $\begin{array}{l}\mathrm{Cu} \\
\mathrm{ppm}\end{array}$ & $\begin{array}{l}\mathrm{Zn} \\
\mathrm{ppm}\end{array}$ & $\begin{array}{l}\text { As } \\
\text { ppm }\end{array}$ & $\begin{array}{l}\text { Co } \\
\text { ppm }\end{array}$ & $\begin{array}{l}\mathrm{Ni} \\
\mathrm{ppm}\end{array}$ & $\begin{array}{l}\mathrm{Cr} \\
\mathrm{ppm}\end{array}$ \\
\hline UCC (McLennan et al. 2006) & 65.8 & 15.2 & 4.5 & 4.2 & 107 & 17 & 25 & 71 & 2 & 17 & 44 & 83 \\
\hline Local bedrock & 54.2 & 14.6 & 5.5 & 6.7 & 108.1 & 17.6 & 35.0 & 93.3 & 5.6 & 14.3 & 36.1 & 78.9 \\
\hline
\end{tabular}

\section{Enrichment factors based on global UCC composition}

In the bulk fraction of the 15 lacustrine cores samples, As is always moderately enriched while $\mathrm{Zn}$ is slightly enriched in the $\mathrm{a} / \mathrm{R}$ sample only.

As is enriched also in the clay fraction of lacustrine samples with a median of 2.93 and a maximum value of 5.16 in the sample $\mathrm{a} / \mathrm{T} . \mathrm{Cu}, \mathrm{Zn}$, and $\mathrm{Pb}$ are enriched in the same unique sample (V3).

In the 14 fluvio-lacustrine samples, As is moderately enriched in almost all samples (13 out of 14). $\mathrm{Pb}$ and $\mathrm{Zn}$ are enriched in very few specimens ( 1 and 2 respectively).

In the 27 Meso-Cenozoic bedrock samples, As is enriched in almost all samples (24) with a median of 4.5 and an extremely significant EF value of 21.36 in the sample EF85 which belongs to the Scisti silicei formation. $\mathrm{Cu}$ is also enriched in eight samples with a significant maximum value of 7.69 in the Gorgoglione Flysch sample EF83. Ni shows enrichment in two samples while $\mathrm{Zn}$ and Co are enriched in just one the sample EF83 (Gorgoglione Flysch).

In the 15 Quaternary deposit samples, As shows enrichment in all samples with a significant maximum of 1.01 in the sample EF54. $\mathrm{Cu}$ and $\mathrm{Pb}$ are slightly enriched respectively in one and three samples.

\section{Enrichment factors based on local bedrock composition}

In the 15 bulk fraction of lacustrine samples, $\mathrm{Pb}$ is enriched in 9 samples while $\mathrm{Zn}$ is enriched in one sample.

In the 15 clay fraction of lacustrine samples, As is enriched in all the 15 sample while $\mathrm{Zn}$ is enriched in one sample.

In the 14 fluvio-lacustrine sediments, $\mathrm{Zn}$ and $\mathrm{Pb}$ are enriched in two samples.

In the 14 Quaternary fluvio-lacustrine samples, $\mathrm{Co}, \mathrm{Ni}$, and As are moderately enriched in one sample (EF54) while $\mathrm{Pb}$ is enriched in 4 samples.

\section{Discussion}

\section{Lake sediment standard quality and the regulatory gap}

The study of heavy metal contamination in an aquatic environment has attracted increasing attention because of its abundance, persistence, and environmental toxicity (Sun et al. 2016; Patel et al. 2018; Wang et al. 2019; Varol et al. 2020). It has been observed that to define more accurately the quality of sediments potentially affected by heavy metals and pollutants, a correct option could be an intensive comparison of applied sediment quality guidelines (SQGs) (Burton 2018; Birch 2018; Liu et al. 2019; Jones et al. 2019). Comparative evaluations of different SQGs for contaminants, in order to obtain an environmental quality and risk assessment of internal waters, has been intensively provided in recent years (Ali et al. 2016; Baran et al. 2016; Bhateria and Jain 2016; Gopal et al. 2017; Strady et al. 2017; Xu et al. 2017; Shyleshchandran et al. 2018; Zhao et al. 2018; Aung et al. 2019; Kulbat and Sokołowska 2019; Christophoridis et al. 2020). It has to be noted that SQGs for the assessment of sediment quality are very different across the different countries. The definition and the approaches to determine guidelines depends from crude percentile rankings of total concentrations of single chemical element to theoretical approaches depending on the biological available effect levels (Burton 2018). A large number of empirical water SQGs, based on matching chemical and biological-effects data, are well established and widely used. Empirical SQGs provide a useful screening tool to identify locations and chemicals of most concern, but are not regulatory criteria. In summary, SGQs vary from empirical to theoretical and are all characterized by a number of uncertainties and, as a consequence, it has been observed that a large number of reviewed SQGs show a considerable range in upper and lower guideline values (Birch 2018). Therefore, since a unique and homogeneous SQG value does not exist, there is a significant regulatory gap about dangerous substances in sediments of internal waters. The European Directive on Environmental Quality Standards (Directive 2008/105/EC), based on the Water Framework Directive (2000/60/EC), sets environmental quality standards (EQS) for the substances in surface waters (fluvial, lacustrine, transitional, and coastal) but not in its sediments. To overcome this gap, Member States may establish an approach for the definition of the admitted threshold values for dangerous substances in sediments. Commonly, the threshold values for dangerous elements in soils are used. Italy implemented the Water Framework Directive by a Legislative Decree "Decreto Legislativo 3 aprile 2006, n. 152 , Norme in materia ambientale" which shows a great interest in aquatic systems but does not contain specific quality 
standards for river or lake sediments. Therefore, even in Italy, the threshold concentration values (CSC) for soils, laid down in the Single Environmental Text and subsequent amendments (Column A, Table 1, Annex 5, Title V, Part IV of Legislative Decree 152/06), are used as standards for sediment quality. In order to obtain a clear picture of the quality and dangerousness of the analyzed sediments, a comparison between samples analysis with some legislative references concerning the quality of the sediments has been performed. The following laws have been taken into consideration for the characterization of the chemical status of the analyzed sediments: Decreto 6 novembre 2003, n. 367 (D.M. 367/ 2003) "Regolamento concernente la fissazione di standard di qualità nell'ambiente acquatico per le sostanze pericolose" and Canadian Council of Ministers of the Environment (CCME 2011), "Canadian Sediment Quality Guidelines for the Protection of Aquatic Life". These laws cover the limit concentrations of chemical elements in the marine environment including lake sediments.

Relatively of Italian legislation (D.M. 367/2003), in the bulk fraction of fifteen lacustrine samples, $\mathrm{Cr}$ exceeds the limit threshold in all samples, $\mathrm{Ni}$ in thirteen samples while $\mathrm{Pb}$ exceeds the limit just in one sample. Concerning the clay fraction of the same samples, $\mathrm{Pb}, \mathrm{Ni}$, and $\mathrm{Cr}$ overcome the limits in all samples (fifteen). In the fourteen fluvio-lacustrine samples, $\mathrm{Ni}$ and $\mathrm{Cr}$ exceed the limit threshold in all samples while $\mathrm{Pb}$ shows the same trend in three samples. In the twenty-seven Meso-Cenozoic lithoid samples, Ni exceeds limit values in twenty samples, $\mathrm{Cr}$ in all twenty-seven samples, and As in one sample. In the fifteen incoherent Quaternary parent rock samples, Ni and Cr exceed limit threshold in fourteen samples, $\mathrm{Pb}$ in eight samples, and As in three samples.

In the bulk fraction of fifteen lacustrine samples, almost all samples show higher values that exceed the limit threshold for $\mathrm{Cu}$ (thirteen samples), As (four samples), and $\mathrm{Cr}$ (fifteen samples) while $\mathrm{Zn}$ exceeds the limit in two samples. Also in the clay fraction of the same samples, almost all samples show higher values which exceed the limit threshold for some elements: $\mathrm{Cu}, \mathrm{Zn}$, and $\mathrm{Cr}$ exceed limits in all the samples, As in fourteen samples, and $\mathrm{Pb}$ in eleven samples. In the fourteen fluvio-lacustrine samples $\mathrm{Cr}$ exceeds limit values in all samples (fourteen), $\mathrm{Zn}$ in twelve samples, and As in ten samples. In the twenty-seven Meso-Cenozoic lithoid samples, $\mathrm{Cr}$ always exceeds limit values in all samples, $\mathrm{Cu}$ in twelve samples, As in eight samples, and $\mathrm{Zn}$ in two samples. In the fifteen Quaternary incoherent parent rock samples, $\mathrm{Cr}$ exceeds the limit threshold in all the samples and $\mathrm{Cu}$ and $\mathrm{As}$ in twelve samples while $\mathrm{Pb}$ and $\mathrm{Zn}$ exceed limit values in five samples.

Comparing the different concentration limits, a difference for chemical elements limits was observed (Table 6). It is important to note that the two considered regulations do not consider the same chemical elements. The Canadian ISQGs do not include V, Co, and Ni while the Italian D.M.367/03
Table 6 Threshold limit concentration for both Italian D.M. 367/03 and Canadian ISQGs 2001 regulations

\begin{tabular}{|c|c|c|c|c|c|c|c|c|}
\hline & $\begin{array}{l}\mathrm{V} \\
\mathrm{ppm}\end{array}$ & $\begin{array}{l}\mathrm{Pb} \\
\mathrm{ppm}\end{array}$ & $\begin{array}{l}\mathrm{Cu} \\
\mathrm{ppm}\end{array}$ & $\begin{array}{l}\mathrm{Zn} \\
\mathrm{ppm}\end{array}$ & $\begin{array}{l}\text { As } \\
\text { ppm }\end{array}$ & $\begin{array}{l}\text { Co } \\
\text { ppm }\end{array}$ & $\begin{array}{l}\mathrm{Ni} \\
\text { ppm }\end{array}$ & $\begin{array}{l}\mathrm{Cr} \\
\mathrm{ppm}\end{array}$ \\
\hline Italian D.M. 367/03 & nd & 30 & nd & nd & 12 & nd & 30 & 50 \\
\hline $\begin{array}{l}\text { Canadian ISQGs } \\
2001\end{array}$ & nd & 35 & 35.7 & 123 & 5.9 & nd & nd & 37 \\
\hline
\end{tabular}

nd $=$ not detected.

does not consider $\mathrm{V}, \mathrm{Cu}, \mathrm{Zn}$, and $\mathrm{Co}$. Therefore, mismatches between the two regulations have been observed as well. For this reason, a comparison between chemical elements considered in both regulations $(\mathrm{Cr}, \mathrm{Pb}$, and $\mathrm{As})$ has been proposed. Furthermore, limit values for $\mathrm{Cu}, \mathrm{Zn}$, and $\mathrm{Ni}$ have been observed as well.

In the lacustrine sediments (both bulk and clay fraction), $\mathrm{Cr}$ exceeds the limit in all samples for Italian D.M. 367/03 and Canadian ISQGs. In the fourteen fluvio-lacustrine samples, for ISQGs, $\mathrm{Cr}$ exceeds limit values in all samples, while for D.M. 367/03, Cr overcomes the limit in fourteen samples. In the MesoCenozoic sediments, for ISQGs regulation, all samples exceed the limits, while for D.M. 367/03, the threshold is exceeded in twenty-five samples. All the fifteen quaternary samples show values exceeding the limit values for Canadian ISQGs and for D.M. 367/03 exceeds limit threshold in almost all samples (fourteen out of fifteen).

In the bulk fraction of the fifteen lacustrine samples, $\mathrm{Pb}$ overcomes the limit threshold just in one sample relatively to Italian D.M. 367/03. Differently, in the clay fraction, $\mathrm{Pb}$ overcomes the limits in all samples (for D.M. 367/03) and in eleven samples (for ISQGs). In the fluvio-lacustrine sediments, $\mathrm{Pb}$ overcomes the limit threshold in two and three samples, for Canadian ISQG and D.M. 367/03 regulations, respectively. No samples exceed $\mathrm{Pb}$ limit values in the twenty-seven Meso-Cenozoic sediment samples. In the fifteen quaternary samples, for Canadian ISQGs, Pb exceeds the limit threshold in five samples, while for D.M. 367/03, Pb overcomes limit threshold in eight samples.

For the fifteen bottom lake sediments (clay fraction), for the Canadian ISQG, fourteen samples exceed the threshold, while for the Italian D.M. 367/03, no sample exceeds the limit threshold. For ISQGs, As in the fourteen fluvio-lacustrine sediments exceeds the limit in ten samples, and for D.M. $367 / 03$, no samples exceed limits. In the twenty-seven Meso-Cenozoic sediments, As exceeds the limit in eight samples for ISQGs while just one sample exceeds limit relatively to D.M. 367/03. Finally, in the fifteen incoherent Quaternary deposit samples, As exceeds the threshold in twelve samples, for ISQGs, and three samples for D.M.367/03.

Concerning the other trace elements, relatively to Canadian ISQGs regulation, $\mathrm{Cu}$ exceeds limit threshold 
in a large number of samples. In fifteen lacustrine sediments, $\mathrm{Cu}$ overcomes the limit in thirteen and fifteen samples, in the bulk and clay fraction, respectively. In the fourteen fluvio-lacustrine samples, $\mathrm{Cu}$ exceeds the limit threshold in twelve samples. Always, twelve samples exceeds $\mathrm{Cu}$ limit values in the twenty-seven Meso-Cenozoic lithoid samples, while in the quaternary deposits samples, $\mathrm{Cu}$ overcomes the limit threshold in almost all samples (twelve out of fifteen).

For Canadian ISQGs, Zn exceeds limit values in all fifteen lacustrine samples (clay fraction), while in the fluviolacustrine samples, the $\mathrm{Zn}$ limit threshold is exceeded in twelve samples out of fifteen.

The values of Ni, relatively to Italian D.M. 367/03, overcome the limit values in a large number of samples. $\mathrm{Ni}$ in all lacustrine (clay fraction), fluvio-lacustrine, and quaternary sediments samples exceeds the limit threshold.

In the bulk fraction of the fifteen lacustrine samples, Ni overcomes limit the threshold in thirteen samples while, in the Meso-Cenozoic lithoid samples, Ni exceeds limit values in twenty samples out of twenty-seven.

Figure 7 shows selected trace element ( $\mathrm{Pb}$ and $\mathrm{As}$ ) composition in the analyzed samples, in relation with the considered normative admitted limit threesholds.

In order to establish the quality of an environment from the environmental and pollution point of view, it would be useful to define a common and homogeneous regulatory reference for all countries, taking into account the same pollutants in the different environments. Considering the regulatory gap affecting fluvio-lacustrine and lacustrine sediments, we will discuss the data of the Pietra del Pertusillo catchment mostly considering the distribution of elements with respect to the local upper continental crust. This may represent an innovative approach under similar conditions worldwide.

\section{Minero-chemical processes and trace elements within the reservoir sediments}

Lacustrine sediments are commonly used for the study of the erosion history of the watershed and to understand the processes, both natural and anthropogenic, affecting the concentration and the mobility of trace elements in water and sediments (Islam et al. 2015; Gao et al. 2017).

Mineralogy of studied samples reflects the parent rock composition. Quartz is the main allogenic phase, derived from the silico-clastic rocks outcropping around the lake basin. Only in the samples from the cores $\mathrm{T}$ and $\mathrm{V}$, calcite is higher than quartz, a finding consistent with the higher values of total organic carbon (TOC) in these cores. Dolomite, likely supplied by the Campano-Lucana carbonate platform units, was found only in the F core. The distribution of feldspars in lacustrine sediments, as well as quartz, also reflects the composition of lithologies outcropping along the drainage basin. Higher amounts of feldspars were found in the cores R, T, and V near the silico-clastic deposits (Gorgoglione and Albidona fms.). Clay minerals like illite and chlorite represent the weathering product of rocks in the drainage basin. The presence of chlorite could be associated with the weathering of mafic silicates-rich rocks, such as Lagonegro basin lithologies (Scisti silicei and Galestri fms.), Liguride unit deposits, and Albidona Fm.

The elemental concentration of sediments not only depends on anthropogenic and lithogenic sources but also upon $\mathrm{pH}$, organic matter content, mineralogical composition, and depositional environments of sediments (e.g., Alyazichi et al. 2014, 2016; Hsu et al. 2016). The dissolved concentrations of trace metals with depth are expected to be controlled by sorption processes and/or by the dissolution/precipitation of their discrete secondary minerals and organic matter (Ho et al. 2012; Alyazichi et al. 2016). Clay and organic matter contents are often used to calculate 'corrected' background values for trace metal concentrations in soils and sediments. Clay minerals largely affect metal clay retention (e.g., Mongelli 1995); Malla (2002) and Jones et al. (2019), for instance, observed the effective adsorbing of $2: 1$ clay minerals of bivalent cations such as $\mathrm{Cu}, \mathrm{Pb}, \mathrm{Cd}$, and $\mathrm{Zn}$. The solubility of trace elements, such as $\mathrm{Cu}, \mathrm{Cr}, \mathrm{Pb}$, and $\mathrm{Zn}$ (Alyazichi et al. 2015), may be also associated to Mn oxides through coprecipitation and substitution and may increase when Mn is reduced (Negra et al. 2005).

In the studied samples, the trace elements which could be relevant from an environmental point of view are $\mathrm{Cr}, \mathrm{Cu}, \mathrm{Zn}$, $\mathrm{As}$, and $\mathrm{Pb}$. Determination of toxic metals in water sediments makes it possible to assess the potential migration of metals from sediments to water and the potential toxicity of metals (Pejman et al. 2015; Palleiro et al. 2016).

$\mathrm{Cr}$ is a very common pollutant in soils, aquifers, and superficial water, where it is stable in hexavalent form (Margiotta et al. 2012; Margiotta et al. 2014). Chromium occurs in more than one oxidation state, and its solubility in the soil depends on $\mathrm{pH}$ and mineral content. $\mathrm{Cr}^{3+}$ has low solubility, whereas hexavalent chromium is adsorbed onto $\mathrm{Fe}, \mathrm{Mn}$, and $\mathrm{Al}$ oxyhydroxides and clay minerals (e.g., Davis and Lackie 1980). Recently (Mwamburi 2016) and less recent works (Griffin et al. 1977) demonstrated that the adsorption of $\mathrm{Cr}$ by clay minerals was found to be highly dependent upon the physical-chemical properties of the clay minerals. This is consistent with the presence of $\mathrm{Cr}$ in the analyzed samples where $\mathrm{Cr}$ is enriched in the fine fraction of lake sediments and, more in general, $\mathrm{Cr}$ is more abundant in samples with larger occurrence of clay minerals such as chlorite.

Yang and Rose (2005) suggested that $\mathrm{Cu}$ occurrence in soils mostly depends on mineral composition, and Cavallaro and McBride (1978) observed that clayey minerals act as the receptor for $\mathrm{Cu}$ in non-calcareous soils. $\mathrm{Cu}$, in our case, is particularly abundant in rocks containing mafic minerals 

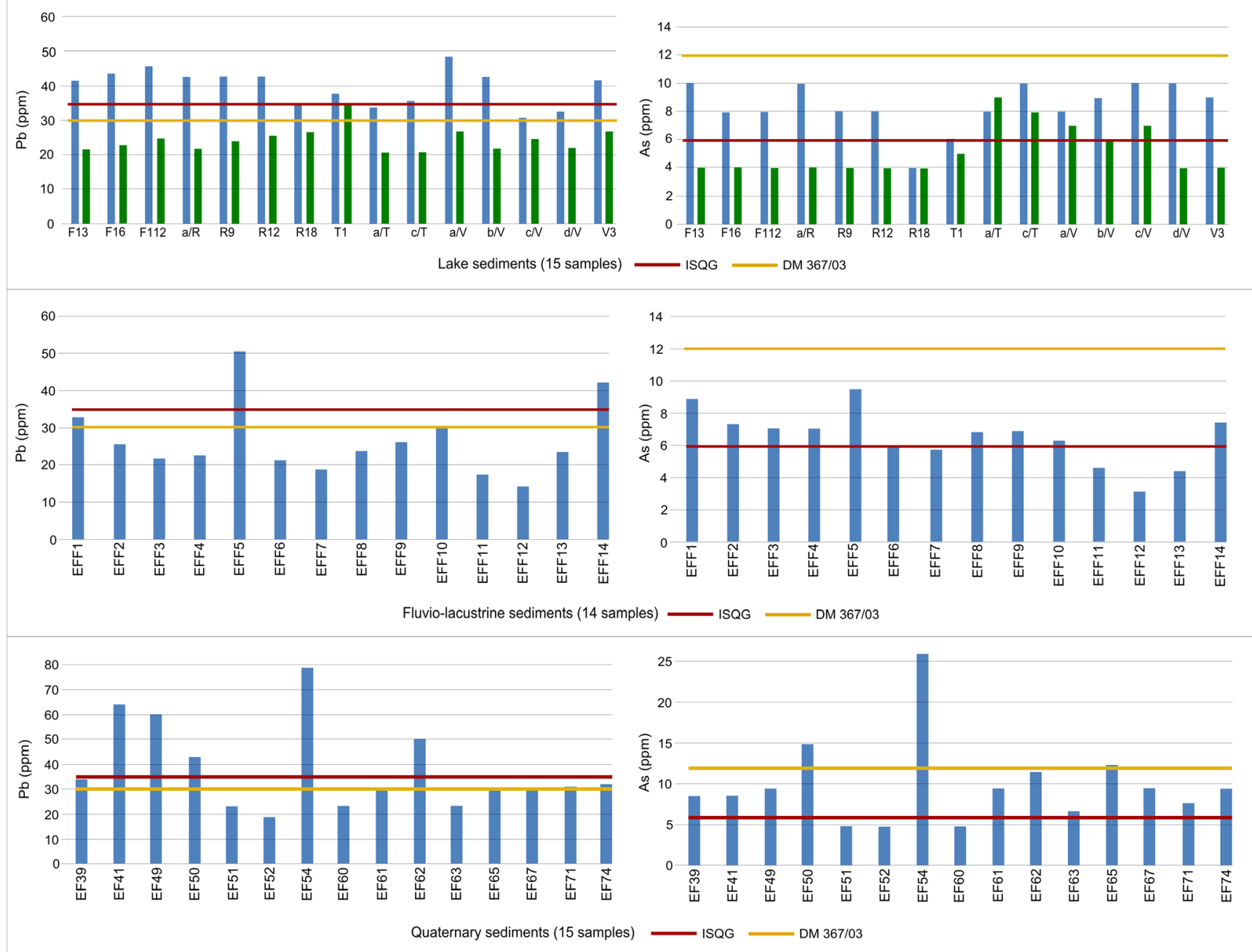

Fig. 7 Chemical composition of selected trace elements ( $\mathrm{Pb}$ and $\mathrm{As}$ ) in relation with threshold values of the considered regulations (Canadian ISQGs and Italian D.M. 367/03). Note that, in lacustrine sediments, blue lines represent clay fraction while green line represent bulk fraction

(Gorgoglione, Galestri, and Albidona Fms) and is enriched in some present-day sediments at Maglia river mouth, suggesting that $\mathrm{Cu}$ is associated with the secondary phases deriving by the weathering of mafic silicates.

Zinc is adsorbed by clay minerals (Uddin 2017), carbonates, or oxides-hydrates, and Tessier et al. (1980), Kuo et al. (1983), and Hickey and Kittrick (1984) found that the highest percentage of $\mathrm{Zn}$ in sediments is associated with Fe-Mn oxides. $\mathrm{Zn}$ is enriched with respect to the local upper continental crust in very few samples including one sample from the core $\mathrm{R}$ and two fluvio-lacustrine samples showing $\mathrm{EF}>2$, suggesting that naturally occurring local conditions may affect the $\mathrm{Zn}$ distribution in the analyzed catchment.

$\mathrm{Pb}$, which is enriched in most of the lacustrine sediments and specifically in the fine fraction, is generally effectively adsorbed onto clay minerals (up to $95 \%$ of available $\mathrm{Pb}$ ) at $\mathrm{pH}$ ranging from 3.0 to 4.5 (Scrudato and Estes 1975). Due to its great mobility, $\mathrm{Pb}$ can be mobilized and transported from the outcropping rocks toward the reservoir, where it is likely absorbed by the most reactive phases, including clay mineral and $\mathrm{Fe}-\mathrm{Mn}$ oxyhydroxides.

As is constantly enriched in the lacustrine samples, and it is well-known that the occurrence of elevated concentrations of As in sediments can compromise soil and water quality since it is one of the most toxic elements in the environment. The toxicity and mobility of arsenic in the environment are determined by a complex series of controls dependent on mineralogy, chemical speciation, and biological processes (Bowell et al. 2014). As occurs as multiple oxidation state element, and its distribution in sediment depends on the sediment redox state (Yang and Rose 2005). In soil and sediments, the availability of As is also affected by the chemical and physical features of sediments including the presence of clay minerals, Al-Fe hydroxides, organic matter content, $\mathrm{pH}$, Eh, and cationexchange capability (El Bilali et al. 2002; Shrivastava et al. 2015). The mobilization of As into the hydrosphere is linked with a combination of natural processes such as weathering reactions, biological activity, mineral-water interactions, and 
through a number of other anthropogenic activities (Chakraborti et al. 2017). As-enriched sediments are a possible source of As to water (Ying et al. 2013) and, in our reservoir system, this element is largely concentrated in the fine fraction of the lacustrine samples ( $\mathrm{EF}>2$ with respect to the local upper crustal composition). This finding reflects the adsorption capability of the fine fraction of the sediment from which, potentially, significant amount of As may move toward the fluid matrix causing water pollution.

\section{Conclusions}

Freshwater reservoir role a great interest for the evaluation of environmental contamination as they are generally located close to several human activities and sources of pollution. In particular, lake sediments act as good receptors for different pollutants; therefore, this kind of sediments has a great impact on the health of citizens and environment. For these reasons, and for the first time, the Pietra del Pertusillo reservoir lake sediments and fluvio-lacustrine sediments have been analyzed to assess environmental quality. Although the definition of the pollution status of a natural environment is an issue of great importance worldwide, in Italy, specific regulatory values for the element threshold concentration for the lake and river sediments do not exist. For this reason, soil threshold values are used as a standard for sediments of internal waters. Further, in order to define the qualitative state of the reservoir, by comparing elemental concentrations of analyzed sediments with limit values of the considered regulations (Italian D.M. 367/03 and the Canadian ISQGs), significant differences and mismatches were observed.

Within this scenario, the evaluation of the environmental quality depicted by the lacustrine and fluvio-lacustrine sediments of the Pietra el Pertusillo reservoir has been performed on the basis of the enrichment factors with respect to the average composition of a restored local upper continental crust. We suggest this method as an innovative standard in similar conditions worldwide. In our catchment, the enrichment factors indicate that the trace elements that may be of some environmental concern are $\mathrm{Cr}, \mathrm{Cu}, \mathrm{Zn}, \mathrm{As}$, and $\mathrm{Pb}$, although the distribution of these elements, at this stage, appear to be mostly driven by geogenic processes. However, attention has to be paid to As, constantly enriched in the lacustrine samples and especially in the fine-grained fraction. Large concentrations of As, considered one of the most relevant contaminant for the environment and health, may potentially compromise sediments and water quality. Arsenic is highly toxic in its inorganic form, and soluble inorganic arsenic can have immediate toxic effects for human health.
Finally, the effects of toxic pollutants on health and environment do not change for the different countries of the planet and therefore this criticality leads us to suggest a worldwide and homogeneous regulatory framework for an effective assessment of the quality status of natural materials in different environments.

Acknowledgments The authors are also indebted to Prof. Mario Bentivenga and Prof. Albina Colella for their support during the sampling activities and Vincenzo Tolla for laboratory analysis work on sediment cores. Part of the work is related with Elisabetta Fortunato Ph.D. thesis.

Author's contributions The manuscript drafting and graphic illustration work was carried out by RB and EF. The sampling activity was conducted by EF and MP. RB, MP, and GM worked at geochemical data elaboration while mineralogical analysis were performed by EF and RS. The elaboration and discussion of mineralogical data were carried out by EF, RS, GR and VS. Finally, the work has been supervised by GM.

Funding Open access funding provided by Università degli Studi della Basilicata within the CRUI-CARE Agreement. This research work was supported by Fondazione Enrico Mattei (FEEM) funds according to a research agreement with the Department of Sciences of University of Basilicata.

Availability of data and materials All data generated or analyzed during this study are included in this published article (and its supplementary information files).

\section{Compliance with ethical standards}

Conflict of interest The authors declare that they have no competing interests.

Ethics approval and consent to participate Not applicable for this section.

Consent for publication Not applicable for this section.

Open Access This article is licensed under a Creative Commons Attribution 4.0 International License, which permits use, sharing, adaptation, distribution and reproduction in any medium or format, as long as you give appropriate credit to the original author(s) and the source, provide a link to the Creative Commons licence, and indicate if changes were made. The images or other third party material in this article are included in the article's Creative Commons licence, unless indicated otherwise in a credit line to the material. If material is not included in the article's Creative Commons licence and your intended use is not permitted by statutory regulation or exceeds the permitted use, you will need to obtain permission directly from the copyright holder. To view a copy of this licence, visit http://creativecommons.org/licenses/by/4.0/.

\section{References}

Abraham J, Allen P, Dunbar J, Dworkin SI (1999) Sediment type distribution in reservoirs: sediment source versus morphometry. Environ Geol 38:101-110 
Ali MM, Ali ML, Islam MS, Rahman MZ (2016) Preliminary assessment of heavy metals in water and sediment of Karnaphuli River, Bangladesh. Environ Nanotechnol Monit Manag 5:27-35

Alyazichi YM, Jones BG, McLean E (2014) Spatial and temporal distribution and pollution assessment of trace metals in marine sediments in Oyster Bay, NSW, Australia. J Bull Environ Contam Toxicol 94: 52-57

Alyazichi YM, Jones BG, McLean E (2015) Spatial distribution of sediment particles and heavy metal pollution in Gunnamatta Bay, Port Hacking, NSW, Australia. J Reg Stud Marine Sci 2:124-131

Alyazichi YM, Jones BG, McLean E, Pease J, Brown H (2016) Geochemical assessment of trace element pollution in surface sediments from the Georges River, Southern Sydney, Australia. Arch Environ Contam Toxicol 72:247-259

Ammar R, Kazpard V, Wazne M, El Samrani AG, Amacha N, Saad Z, Chou L (2015) Reservoir sediments: a sink or source of chemicals at the surface water-soilwater interface. Environ Monit Assess:187579

Audry S, Schäfer J, Blanc G, Jouanneau JM (2004) Fifty-year sedimentary record of heavy metal pollution $(\mathrm{Cd}, \mathrm{Zn}, \mathrm{Cu}, \mathrm{Pb})$ in the Lot River reservoirs (France). Environ Pollut 132:413-426

Aung PP, Mao Y, Hu T, Qi S, Tian Q, Chen Z, Xing X (2019) Metal concentrations and pollution assessment in bottom sediments from Inle Lake, Myanmar. J Geochem Explor 207:106357

Baran A, Tarnawski M, Koniarz T (2016) Spatial distribution of trace elements and ecotoxicity of bottom sediments in Rybnik reservoir, Silesian-Poland. Environ Sci Pollut Res 23:17255-17268

Bhateria R, Jain D (2016) Water quality assessment of lake water: a review. Sustain Water Resour Manag 2:161-173

Birch GF (2018) A review of chemical-based sediment quality assessment methodologies for the marine environment. Mar Pollut Bull 133:218-232

Bowell RJ, Alpers CN, Jamieson HE, Nordstrom DK, Majzlan J (2014) The environmental geochemistry of arsenic-an overview. Rev Mineral Geochem 79(1):1-16

Burton GA (2018) Breaking from tradition: establishing more realistic sediment quality guidelines. Environ Sci Pollut Res 25(4):30473052

Carbone S, Catalano S, Lazzari S, Lentini F, Monaco C (1991) Presentazione della Carta Geologica del Bacino del fiume Agri (Basilicata) (Italian). Mem Soc Geol It 47:129-143 (in Italian)

Cavallaro N, McBride MB (1978) Copper and cadmium adsorption characteristics of selected acid and calcareous soils. Soil Sci Soc Am J 42(4):550-556

CCME (2011) Canadian sediment quality guidelines for the protection of aquatic life. Canadian Council of Ministers of the Environment (http://ceqg-rcqe.ccme.ca/download/en/226)

Chakraborti D, Rahman MM, Das B, Chatterjee A, Das D, Nayak B, Pal A, Chowdhury UK, Ahmed S, Biswas BK, Sengupta MK, Hossain MA, Samanta G, Roy MM, Dutta RN, Saha KC, Mukherjee SC, Pati S, Kar PB, Mukherjee A, Kumar M (2017) Groundwater arsenic contamination and its health effects in India. Hydrogeol J 25: $1165-1181$

Christophoridis C, Evgenakis E, Bourliva A, Papadopoulou L, Fytianos K (2020) Concentration, fractionation, and ecological risk assessment of heavy metals and phosphorus in surface sediments from lakes in N. Greece. Environ Geochem Health

Davis JA, Lackie JO (1980) Surface ionization and complexation at the oxide/water interfase 3. Adsorption of anions. J Colloid Interface Sci 74:32-43

De Vivo B, Lima A, Siegel FR (2004) Geochimica ambientale. Metalli potenzialmente tossici. Liguore Editore, pp. 464 (in Italian)

Decreto 6 novembre 2003, n. 367. Ministero dell'Ambiente e della Tutela del Territorio. Regolamento concernente la fissazione di standard di qualità nell'ambiente acquatico per le sostanze pericolose, ai sensi dell'articolo 3, comma 4, del decreto legislativo 11 maggio 1999, $\mathrm{n}$. 152 (in Italian)

Decreto Legislativo 3 aprile 2006, n. 152, Norme in materia ambientale (in Italian)

El Bilali L, Rasmussen PE, Hall GEM, Fortin D (2002) Role of sediment composition in trace metal distribution in lake sediments. Appl Geochem 9:1171-1181

Farkas A, Erratico C, Vigano L (2007) Assessment of the environmental significance of heavy metal pollution in surficial sediments of the River Po. Chemosphere 68:761-768

Gao L, Wang Z, Shan J, Chen J, Tang C, Yi M (2017) Aquatic environmental changes and anthropogenic activities reflected by the sedimentary records of the Shima River, Southern China. Environ Pollut 224:70-81

Gao L, Wang Z, Li S, Chen J (2018) Bioavailability and toxicity of trace metals $(\mathrm{Cd}, \mathrm{Cr}, \mathrm{Cu}, \mathrm{Ni}$, and $\mathrm{Zn})$ in sediment cores from the Shima River, South China. Chemosphere 192:31-42

Giano SI (2011) Quaternary alluvial fan systems of the Agri intermontane basin (southern Italy): tectonic and climatic controls. Geol Carpath 62(1):65-76

Giocoli A, Stabile TA, Adurno I, Perrone A, Gallipoli MR, Gueguen E, Norelli E, Piscitelli S (2015) Geological and geophysical characterization of the High Agri Valley. Nat Hazards Earth Syst Sci 15:315323

Gopal V, Achyuthan H, Jayaprakash M (2017) Assessment of trace elements in Yercaud Lake sediments, southern India. Environ Earth Sci $76: 63$

Griffin RA, Au AK, Frost RR (1977) Effect of pH on adsorption of chromium from landfill leachate by clay minerals. J Environ Sci Health Part A Environ Sci Eng 128:431-449

Gueguen E, Bentivenga M, Colaiacovo R, Margiotta S, Summa V, Adurno I (2015) The Verdesca landslide in the Agri Valley (Basilicata, Southern Italy). Nat Hazards Earth Syst Sci 15:25852595

Hakanson L, Jansson M (1983) Principles of lake sedimentology. Springer-Verlag, Berlin Heidelberg, p 320

Harikumar PS, Nasir UP, Rahman MM (2009) Distribution of heavy metals in the core sediments of a tropical wetland system. Int J Environ Sci Technol 6(2):225-232

Hickey MG, Kittrick JA (1984) Chemical partitioning of cadmium, copper, nickel and zinc in soils and sediments containing high levels of heavy metals 1. J Environ Qual 13(3):372-376

Ho HH, Swennen R, Cappuyns V, Vassilieva E, Van Gerven T, Van Tran $\mathrm{T}$ (2012) Potential release of selected trace elements (As, Cd, Cu, $\mathrm{Mn}, \mathrm{Pb}$ and $\mathrm{Zn}$ ) from sediments in Cam River-mouth (Vietnam) under influence of $\mathrm{pH}$ and oxidation. Sci Total Environ 435-436: $487-498$

Hsu L, Huang C, Chuang Y, Chen H, Chan Y, Teah H, Chen T, Chang C, Liu Y, Tzou Y (2016) Accumulation of heavy metals and trace elements in fluvial sediments received effluents from traditional and semiconductor industries. Sci Rep 6:34250

Islam MS, Ahmed MK, Habibullah-Al-Mamun M, Hoque MF (2015) Preliminary assessment of heavy metal contamination in surface sediments from a river in Bangladesh. Environ Earth Sci 73:18371848

Jones B, Alyazichi YM, Low C, Goodfellow A, Chenhall B, Morrison J (2019) Distribution and sources of trace element pollutants in the sediments of the industrialized Port Kembla Harbour, New South Wales, Australia. J Environ Earth Sci

Kulbat E, Sokołowska A (2019) Methods of assessment of metal contamination in bottom sediments (case study: Straszyn Lake, Poland). Arch Environ Contam Toxicol 77:605-618

Kuo SA, Heilman PE, Baker AS (1983) Distribution and forms of copper, zinc, cadmium, iron, and manganese in soils near a copper smelter1. Soil Sci 135(2):101-109 
Liu R, Bao K, Yao S, Yang F, Wang X (2018) Ecological risk assessment and distribution of potentially harmful trace elements in lake sediments of Songnen Plain, NE China. Ecotoxicol Environ Saf 163: $117-124$

Liu H, Zhang K, Chai L, Yang Z, Yang W, Liao Q, Li H, Liu Y (2019) A comparative evaluation of different sediment quality guidelines for metal and metalloid pollution in the Xiangjiang River, Hunan, China. Arch Environ Contam Toxicol 73:593-606

Malla PB (2002) Vermiculites. In "Soil mineralogy with environmental applications" (J. B. Dixon and D. G. Schulze, Eds.), SSSA Chapter 16, pp. 501-529

Margiotta S, Mongelli G, Summa V, Paternoster M, Fiore S (2012) Trace element distribution and $\mathrm{Cr}$ (VI) speciation in $\mathrm{Ca}-\mathrm{HCO}_{3}$ and $\mathrm{Mg}$ $\mathrm{HCO}_{3}$ spring waters from the northern sector of the Pollino massif, southern Italy. J Geochem Explor 115:1-12

Margiotta S, Mongelli G, Paternoster M, Sinisi R, Summa V (2014) Seasonal groundwater monitoring for trace elements distribution and $\mathrm{Cr}$ (VI) pollution in an area affected by negligible anthropogenic effects. Fresenius Environ Bull 23(12):1-13

McLennan SM, Taylor SR, Hemming SR (2006) Composition differentiation and evolution of continental crust: constraints from sedimentary rocks and heat flow. In: Brown, M., Rushmere, T., (eds) Evolution and differentiation of continental crust. Cambridge pp 377

Mongelli G (1995) Trace elements distribution and mineralogical composition in the $<2 \mu \mathrm{m}$ fraction of shales from the Southern Apennines, Italy. Mineral Petrol 53:103-114

Mongelli G, Paternoster M, Rizzo G, Sinisi R (2014a) Trace elements and REE fractionation in subsoils developed on sedimentary and volcanic rocks: case study of the Mt. Vulture area, southern Italy. Int J Earth Sci 103:1125-1140

Mongelli G, Boni M, Buccione R, Sinisi R (2014b) Geochemistry of the Apulian karst bauxites (southern Italy): chemical fractionation and parental affinities. Ore Geol Rev 63:9-21

Mongelli G, Scarfiglieri A, Paternoster M (2015) Groundwater chemistry in the high Agri Valley (Southern Apennines, Italy). Geoacta 4:2542

Mwamburi J (2016) Chromium distribution and spatial variations in the finer sediment grain size fraction and unfractioned surficial sediments on Nyanza Gulf, of Lake Victoria (East Africa). J Waste Manag 2016:15

Negra C, Ross DS, Lanzirotti A (2005) Soil manganese oxides and trace metals competitive sorption and microfocused synchrotron X-ray fluorescence mapping. Soil Sci Soc Am J 69:353-361

Palleiro L, Patinha C, Rodríguez-Blanco ML, Taboada-Castro MM, Taboada-Castro MT (2016) Metal fractionation in topsoils and bed sediments in the Mero River rural basin: bioavailability and relationship with soil and sediment properties. Catena 144:34-44

Patel P, Raju NJ, Reddy BCSR, Suresh U, Sanjar DB, Reddy TVK (2018) Heavy metal contamination in river water and sediments of the Swarnamukhi River basin, India: risk assessment and environmental implications. Environ Geochem Health 40:609-623

Pejman A, Nabi Bidhendi G, Ardestani M, Saeedi M, Baghvand A (2015) A new index for assessing metals contamination in sediments: a case study. Ecol Indic 58:365-373

Prosser G. Schiattarella M, Tramutoli M, Doglioni C, Harabaglia P, Bigozzi A (1996). Una sezione rappresentativa dell'Appennino Meridionale. Conferenza sulla Ricerca Scientifica in Basilicata, Potenza, 29 Febbraio - 1 Marzo (in Italian)

Reimann C, De Caritat P (2005) Distinguishing between natural and anthropogenic sources for elements in the environment: regional geochemical surveys versus enrichment factors. Sci Total Environ 337(1-3):91-107

Scrudato RJ, Estes EL (1975) Clay-lead sorption relations. Geo 1:167-170
Shrivastava A, Ghosh D, Dash A, Bose S (2015) Arsenic contamination in soil and sediment in India: sources, effects, and remediation. Curr Pollution Rep 1:35-46

Shyleshchandran MN, Mohan M, Ramasamy EV (2018) Risk assessment of heavy metals in Vembanad Lake sediments (south-west coast of India), based on acid-volatile sulfide (AVS) simultaneously extracted metal (SEM) approach. Environ Sci Pollut Res 25:7333-7345

Strady E, Dinh QT, Némery J, Nguyen TN, Guédron S, Nguyen NS, Denis H, Nguyen PD (2017) Spatial variation and risk assessment of trace metals in water and sediment of the Mekong Delta. Chemosphere 179:367-378

Sun Q, Ding S, Wang Y, Xu L, Wang D, Chen J, Zhang C (2016) In-situ characterization and assessment of arsenic mobility in lake sediments. Environ Pollut 214:314-323

Sutherland RA (2000) Depth variation in copper, lead, and zinc concentrations and mass enrichment ratios in soils of an urban watershed. J Environ Qual 29:1414-1422

Tessier A, Campbell PGC, Bisson M (1980) Trace metal speciation in the Yamaska and St. Francois rivers (Quebec). Can J Earth Sci 17(1): 90-105

Tuikka AI, Schmitt C, Höss S, Bandow N, Von der Ohe PC, De Zwart D, de Deckereb EG, Streckd G, Mothesd S, van Hattumf B, Kocang A, Brixh R, Brackd W, Barcelóh D, Sormunena AJ, Kukkonena JVK (2011) Toxicity assessment of sediments from three European river basins using a sediment contact test battery. Ecotoxicol Environ Saf 74(1):123-131

Uddin MK (2017) A review on the adsorption of heavy metals by clay minerals, with special focus on the past decade. Chem Eng J 308: $438-462$

Varol M, Canpolat O, Eriş KK, Çağlar M (2020) Trace metals in core sediments from a deep lake in eastern Turkey: vertical concentration profiles, eco-environmental risks and possible sources. Ecotoxicol Environ Saf 189:110060

Wang Z, Zhou J, Zhang C, Qu L, Mei K, Dahlgren RA, Zhang M, Xia F (2019) A comprehensive risk assessment of metals in riverine surface sediments across the rural-urban interface of a rapidly developing watershed. Environ Pollut 245:1022-1030

Xu Y, Wu Y, Han J, Li P (2017) The current status of heavy metal in lake sediments from China. Pollut Ecol Risk Assess 7(14):5454-5466

Yang H, Rose N (2005) Trace element pollution records in some UK lake sediments, their history, influence factors and regional differences. Environ Int 31(1):63-75

Ying SC, Masue-Slowey Y, Kocar BD, Griffis SD, Webb S, Marcus MA, Francis CA, Fendorf S (2013) Distributed microbially- and chemically-mediated redox processes controlling arsenic dynamics within $\mathrm{Mn}-/ \mathrm{Fe}$-oxide constructed aggregates. Geochim Cosmochim Acta 104:29-41

Zembo I (2010) Stratigraphic architecture and quaternary evolution of the Val d'Agri intermontane basin (Southern Apennines, Italy). Sediment Geol 223:206-234

Zhang Y, Han Y, Yang J, Zhu L, Zhong W (2017) Toxicities and risk assessment of heavy metals in sediments of Taihu Lake, China, based on sediment quality guidelines. J Environ Sci 62:31-38

Zhao XM, Yao LI, Ma QL, Zhou GJ, Wang L, Fang QL, Xu ZC (2018) Distribution and ecological risk assessment of cadmium in water and sediment in Longjiang River, China: implication on water quality management after pollution accident. Chemosphere 194:107-116

Zhuang W, Ying SC, Frie AL, Wang Q, Song J, Liu Y, Chen Q, Lai X (2019) Distribution, pollution status, and source apportionment of trace metals in lake sediments under the influence of the South-toNorth Water Transfer Project, China. Sci Total Environ 671:108-118

Publisher's note Springer Nature remains neutral with regard to jurisdictional claims in published maps and institutional affiliations. 